\section{Pacific Northwest} National Laboratory

Operated by Battelle for the

U.S. Department of Energy

\section{Data Catalog for Models Simulating Release of Contaminants from Hanford Site Waste Sources}

R. Riley

C. Lo Presti

August 2003

Prepared for the U.S. Department of Energy under Contract DE-AC06-76RL01830 


\title{
Data Catalog for Models Simulating Release of Contaminants from Hanford Site Waste Sources
}

\author{
R. G. Riley \\ C. A. Lo Presti
}

August 2003

Prepared for

the U.S. Department of Energy

under Contract DE-AC06-76RLO 1830

Pacific Northwest National Laboratory

Richland, Washington 99352 


\section{Forward}

The Characterization of Systems Task under the Groundwater Protection Program is responsible for establishing a consistent set of data, parameters, and conceptual models to support efforts at the Hanford Site to estimate contaminant migration and impacts. As part of these efforts, the Characterization of Systems Task is assembling a series of catalogs to identify the depth and breadth of existing data and to facilitate access to those data. The preparation of these catalogs is aimed at facilitating the development of comprehensive, useable, and scientifically defensible database(s). However, it is also envisioned that these catalogs will be "living documents" that will continue to evolve as other existing data is found and new data collected.

This report is an update of the previously published catalog (Riley and Lo Presti 2001) that summarizes information published since 1987 on models that have been used to simulate release of chemical and radioactive contaminants from waste sources on the Hanford Site. 


\section{Summary}

Models have been used to simulate the transport and fate of contaminants at the Hanford Site to assess the effectiveness of various environmental restoration and waste management activities and to estimate impacts to environmental and human receptors. Part of the process includes the ability to simulate the release to the vadose zone and groundwater of a wide range of contaminants from a wide range of sources that have generated waste at the Hanford Site as a result of over 40 years of defense production activities.

Mathematical formulas that express the release of contaminants from various waste sources and their application in past assessments are documented in many reports published since 1987. The sheer number of reports in which such information is reported makes it difficult for individuals to access this information in a timely manner. To provide people carrying out Hanford assessments with improved access to the information and data on release model capability, researchers at the Pacific Northwest National Laboratory (PNNL) consolidated the information and data into a single location. The initial catalog was published by the Groundwater/Vadose Zone Integration Project managed by Bechtel Hanford, Inc. for the U.S. Department of Energy (DOE) Richland Operations Office. This updated report was supported by the Groundwater Protection Program managed by Fluor Hanford, Inc. for DOE.

This report updates information on release models used in Hanford Site assessments since 1987. Mathematical formulations that commonly have been used in recent years (i.e., liquid, saltcake, cement, soil-debris, reactor block, glass, and reactor compartment) are described, along with associated parameter definitions and their units. Tables in this report provide links to data sources needed to implement the models. These links enable users to quickly locate the specific release model information and data they need to apply the models to future site assessments.

The authors are aware of significant differences in the level of complexity of release models applied over the years to meet Hanford Site assessment objectives. For example, release model capability to support past immobilized low-activity waste (ILAW) performance assessments is far more advanced than the simpler mathematical formulations for glass release used in earlier years and described in this report. The authors, therefore, encourage readers of this report to contact the individuals listed in Table 1.1 of this report for possible additional up-to-date information in their area of interest. 


\section{Acronyms and Abbreviations}

$\begin{array}{ll}\text { DOE } & \text { U.S. Department of Energy } \\ \text { ERDF } & \text { Environmental Restoration Disposal Facility } \\ \text { HDWEIS } & \text { Hanford defense waste environmental impact statement } \\ \text { ILAW } & \text { immobilized low-activity waste } \\ \text { PCB } & \text { polychlorinated biphenyl } \\ \text { PNNL } & \text { Pacific Northwest National Laboratory } \\ \text { RCRA } & \text { Resource Conservation Recovery Act } \\ \text { SAC } & \text { System Assessment Capability }\end{array}$




\section{Contents}

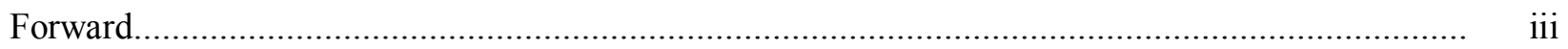

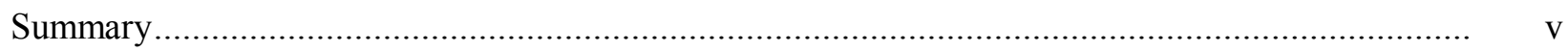

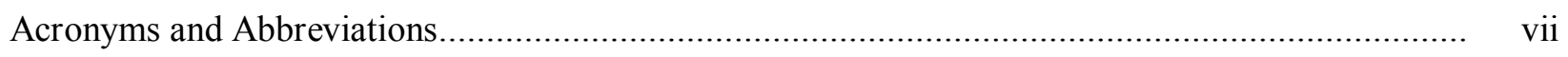

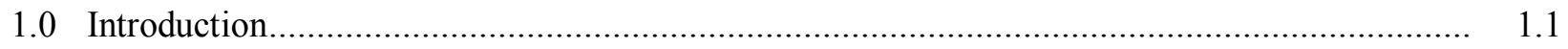

2.0 General Conceptual Model of Contaminant Release from Engineered Waste Systems.............. 2.1

3.0 Release Models Described in Previous Assessments and Reviews........................................ 3.1

3.1 Release from High-Level Waste Tanks ............................................................... 3.9

3.2 Release from Immobilized Low-Level Activity Tank Waste ........................................ 3.9

3.3 Release from Solid Waste Burial Sites .................................................................... 3.11

3.3.1 Release of Contaminants from Low-Level Waste Burial Grounds ....................... 3.11

3.3.2 Release of Contaminants from the Environmental Restoration Disposal Facility..... 3.13

3.3.3 Release from Remediated High Volume Liquid and Solid Waste Disposal Sites ..... 3.13

3.3.4 Release from Grout Vaults .................................................................................... 3.14

3.3.5 Release from Reactor Cores of Production Reactors ......................................... 3.14

3.3.6 Releases of Contaminants from Naval Reactor Compartments............................. 3.15

3.3.7 Releases of Contaminants from Process Facilities .............................................. 3.16

4.0 Release Model Mathematical Formulations and Data Sources ....................................... 4.1

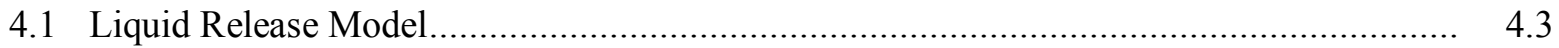

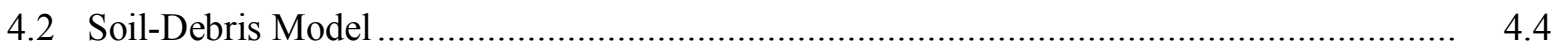

4.2.1 Mathematical Formulations for Soil-Debris Model ............................................ 4.4

4.2.2 Sources of Data for Soil-Debris Model ................................................................. 4.5

4.3 Solubility/Constant Concentration Model ................................................................... 4.12

4.4 Saltcake Model .................................................................................................... 4.12

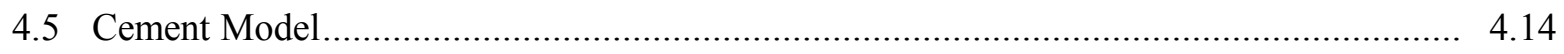

4.6 Reactor Block Model........................................................................................... 4.16

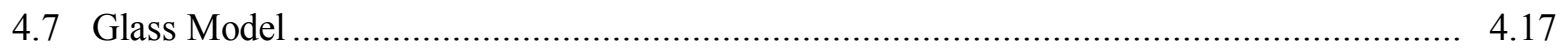

4.8 Reactor Compartment Model ........................................................................ 4.18 
4.9 Containment as a Factor Influencing Release of Contaminants from Source Zones

\section{Figures}

2.1 Basic Features of a Waste Containment Facility

\section{Tables}

1.1 Hanford Contacts for Information on Release Model Capability...................................... 1.2

3.1 Sources of Information on Release Models and Data Relevant to Hanford Assessments ......... 3.1

4.1 Relationship Between Selected Release Formulations Found in Kincaid et al. (1998) and Those Found or Assumed Used in Other Referenced Sources

4.2 Summary of Possible Source-Term Release Model Assignments to Waste Source Types and Associated Assumptions

4.3 Parameters and Data Sources for Release Models

4.4 Sources of Distribution Coefficient Data for Soil-Debris Model.

4.5 Sources of Bulk Density and Moisture Content Data for Soil-Debris Model.

4.6 Sources of Solubility Data for Soil-Debris Model

4.7 Sources of Waste Zone or Waste Form Feature Data for Release Models

4.8 Sources of Recharge Rate Data for Release Models

4.9 Other Sources of Data for Soil-Debris Model.

4.10 Sources of Data for Saltcake Model

4.11 Sources of Data for Cement Model

4.12 Sources of Data for Reactor Block Model 


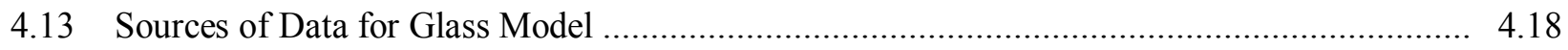

4.14 Sources of Data for Reactor Compartment Model ...................................................... 4.19

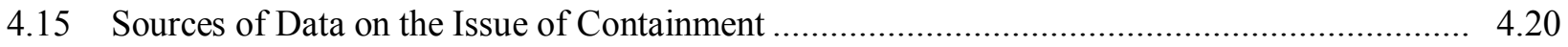




\subsection{Introduction}

Models have been used to simulate the transport and fate of contaminants at the Hanford Site to assess the effectiveness of various environmental restoration and waste management activities and to estimate impacts to environmental and human receptors. Part of the process includes the ability to simulate the release to the vadose zone and groundwater of a wide range of contaminants from a wide range of sources that have generated waste at the Hanford Site as a result of over 40 years of defense production activities.

Mathematical formulas that express the release of contaminants from various waste sources, the parameters important to those formulations and associated parameter data, and their application in past assessments are documented in many reports published since 1987. The sheer number of reports in which such information is reported make it difficult for individuals to access this information in a timely manner. To provide users carrying out Hanford assessments with improved access to the information and data on release model capability, researchers at the Pacific Northwest National Laboratory (PNNL) consolidated these sources of information and data into a single location. Preparation and publication of the initial catalog (Riley and Lo Presti 2001a) was conducted under the Groundwater/Vadose Zone Integration Project managed by Bechtel Hanford, Inc. for the U.S. Department of Energy (DOE) Richland Operations Office. This updated report was supported by the Groundwater Protection Program managed by Fluor Hanford, Inc. for DOE. In addition to providing easier access to past information, consolidation also encourages the standardization of release model capabilities, information, and data on future site assessments with the potential benefit of improving the intercomparability of future assessment results.

The initial report (1) provided a summary of descriptions and uses of release models used in assessments from 1987 to 2001, (2) described analytical solutions for contaminant release from various types of waste sources and assessed their commonality, (3) linked release models to data on various waste sources found on the Hanford Site, and (4) provided listings of sources of parameter information and parameter data used in the models. For purpose four, this report provided links to specific pages, figures, and tables for locating specific information and data within documents.

In this update to the initial report, the contacts list (Table 1.1) has been updated, a conceptual model of release is presented (Chapter 2) that informs the reader of some of the key features and processes that influence contaminant release from Hanford waste sources. In Chapter 3, several additional applications of release models that pertain to assessments of immobilized low-activity waste and solid waste disposal sites are summarized. In Chapter 4, the greatest amount of new data is provided in the area of containment.

The authors recognize that release model capabilities continue to advance. In recognition of this dynamic, we have identified several individuals among the Hanford contractors who can be contacted for information that may be more recent than is cited in this report (Table 1.1). 
The report excludes information on release by way of the atmospheric pathway. Information on release to the atmospheric pathway from near-surface waste sources can be found in a number of previous assessments (Kincaid et al. 1998; Wood et al. 1995a; Wood et al. 1996; Kincaid et al. 1995a; DOE 1989; DOE 1996a, Vol. 5; Streile et al. 1996).

Table 1.1. Hanford Contacts for Information on Release Model Capability (as of August 2003)

\begin{tabular}{||l|l|l||}
\hline \multicolumn{1}{|c|}{ Name, Phone, E-Mail } & Affiliation & \multicolumn{1}{c||}{ Technical Area } \\
\hline $\begin{array}{l}\text { 5harles T. Kincaid } \\
\text { Charley-3576 }\end{array}$ & PNNL & $\begin{array}{l}\text { Release model applications to Hanford assessments (general } \\
\text { knowledge of applications) }\end{array}$ \\
\hline $\begin{array}{l}\text { Charles A. Lo Presti } \\
\text { 509-375-3923 } \\
\text { Charles.lopresti@pnl.gov }\end{array}$ & PNNL & $\begin{array}{l}\text { Development of release model capability within the Hanford } \\
\text { Site System Assessment Capability }\end{array}$ \\
\hline $\begin{array}{l}\text { B. Peter McGrail } \\
\text { 509-376-9193 } \\
\text { Pete.McGrail@pnl.gov }\end{array}$ & PNNL & $\begin{array}{l}\text { Release models for immobilized low-activity waste glass and } \\
\text { high-level waste tank applications }\end{array}$ \\
\hline $\begin{array}{l}\text { Alexander M. Nazarali } \\
\text { 509-372-9098 } \\
\text { amnazara@mail.bhi-erc.com }\end{array}$ & $\begin{array}{l}\text { Hechtel } \\
\text { Inc. }\end{array}$ & $\begin{array}{l}\text { Application of modeling (e.g., RESRAD) to Hanford cleanup } \\
\text { activities }\end{array}$ \\
\hline $\begin{array}{l}\text { Robert G. Riley } \\
\text { 509-376-1935 } \\
\text { Robert.riley@pnl.gov }\end{array}$ & PNNL & $\begin{array}{l}\text { Release model applications in the Hanford Site System } \\
\text { Assessment Capability (general knowledge of applications) }\end{array}$ \\
\hline $\begin{array}{l}\text { William J. Deutsch } \\
\text { 509-376-3422 } \\
\text { Bill.Deutsch@pnl.gov }\end{array}$ & PNNL & Release model applications to high-level waste tank waste \\
\hline $\begin{array}{l}\text { R. Jeff Serne } \\
\text { 509-376-8429 } \\
\text { jeff.serne@pnl.gov }\end{array}$ & PNNL & $\begin{array}{l}\text { Release model applications to Hanford assessments (cement } \\
\text { waste forms and general knowledge of applications) }\end{array}$ \\
\hline $\begin{array}{l}\text { Marcus I. Wood } \\
\text { 509-373-3308 } \\
\text { Marcus_I_Wood@rl.gov }\end{array}$ & HILL & $\begin{array}{l}\text { Release model applications to Hanford assessments (e.g., } \\
\text { low-level waste performance assessments and general } \\
\text { knowledge of applications) }\end{array}$ \\
\hline
\end{tabular}




\subsection{General Conceptual Model of Contaminant Release from Engineered Waste Systems}

Engineered waste systems have a number of features that influence the rate at which contaminants can be released from waste. Those features are illustrated in Figure 2.1. The waste may be placed in some form of trench or reside in a tank. The trench, tank, or other form of engineered structure (repository) serves as a barrier to prevent infiltrating water from making contact with and transporting contaminants from the waste to the vadose zone. Waste inside an engineered system (e.g., trench) may also be contained in a waste package (e.g., metal drum or high integrity concrete container). The drum or concrete container acts as an additional barrier to prevent transport of the contaminants from the waste. The majority of materials used to contain Hanford waste are concrete, steel and bituminous layers, and coatings. The stability and permeability of containment materials compete with each other as to which process dominates the rate at which water contacts the waste and the rate at which contaminants in the waste are released to migrating water. Surface covers atop an engineered system and liners (geomembrane and geosynthetic) and leachate collection systems at the bottom of engineered systems further restrict the ability of infiltrating water to transport contaminants to the vadose zone. Surface covers play a particularly important role in that migration of infiltrating pore water may be limited to a diffusion-controlled process as long as the cover maintains its integrity.

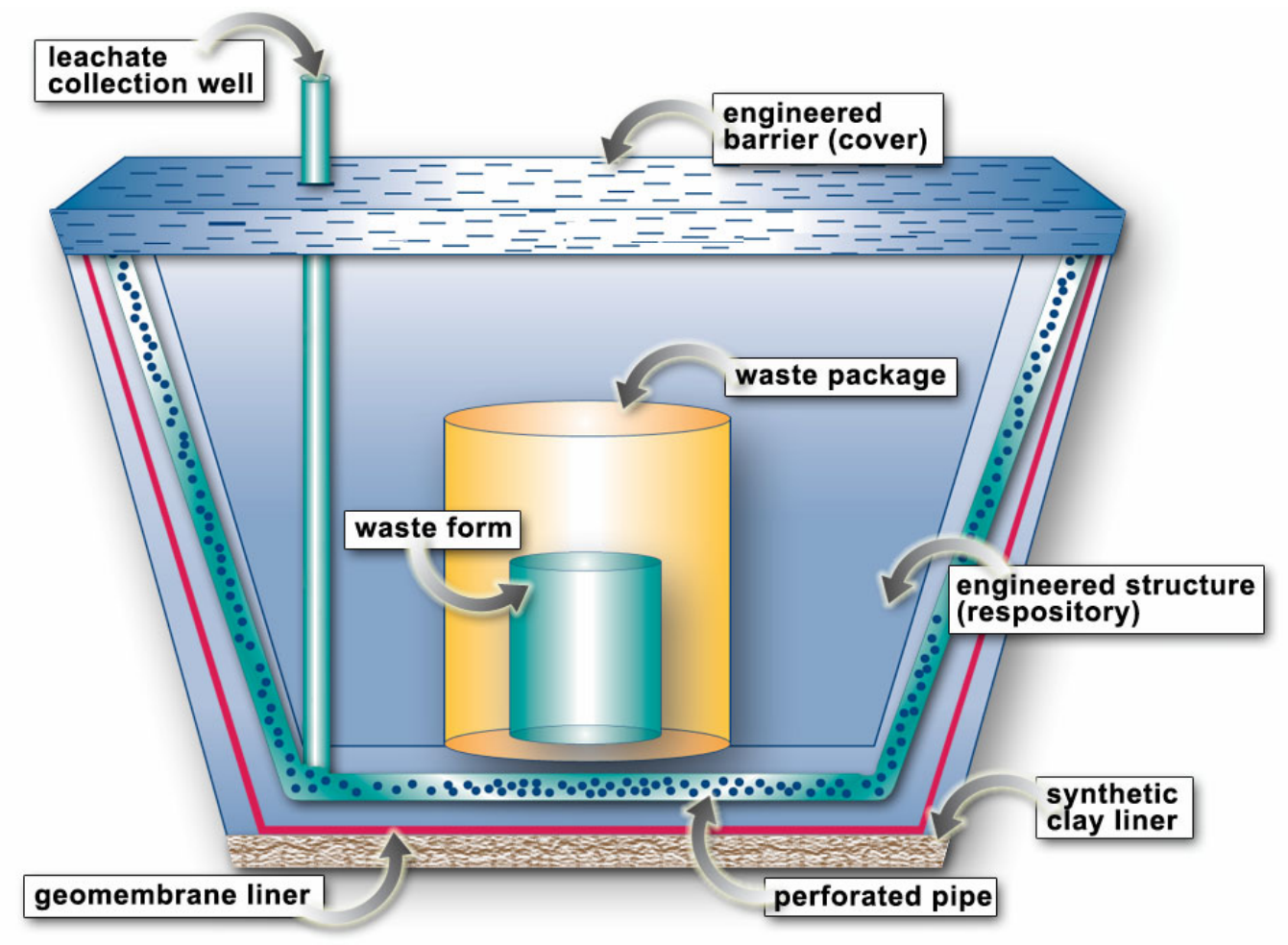

Figure 2.1. Basic Features of a Waste Containment Facility 
A number of key processes govern how much contaminant at any given time is released from the waste to the infiltrating water. One process is the affinity of contaminants to be retained by the waste (e.g., sorption to soil or waste material). Another process involves the ability of waste or waste forms to dissolve and, in some cases, form new precipitates allowing some contaminants to be released to the infiltrating water while others remain trapped in the precipitated solids. Release from the waste may also be limited by the solubility of the contaminant in the infiltrating water. Abiotic and biotic degradation of contaminants may occur in the waste thus reducing the amount of contaminant reaching the vadose zone.

Water infiltrating an engineered system may contact and react with fill materials (e.g., soil, basalt, grout), containment materials in various states of degradation, and different types of waste. Reaction with these materials will result in changes to the chemistry of the water over time. The water's composition, $\mathrm{pH}$, and redox state at any given time will influence the extent to which the processes described in the previous paragraph influence contaminant release from the waste.

Pore water migration in an engineered system is controlled by the permeability of a critical layer comprising the cover atop the engineered system. Critical layers include synthetic geomembranes (i.e., asphalt layers with bituminous coatings) associated with regulatory compliant covers or layers that overcome some of the deficiencies associated with these covers. Migration of pore water under a stable cover will be controlled by diffusion. The ability of the cover to minimize pore water migration will be determined by the quality of the installation (no leakage) and the stability of the critical layer over time. The long-term stability of covers is unknown.

Pore water contact with waste is delayed if the waste is contained in a repository (e.g., tank, vault, high integrity container) or waste package. Containment materials include concrete, steel, bituminous coatings, wood, and cardboard. The stability and permeability of the containment material compete with each other as to which process dominates as migrating pore water moves to make contact with the waste. The corrosive properties of the soil are a key factor in determining concrete and steel stability. The potential for carbonate formation also influences concrete stability. The stability of containment materials such as wood and cardboard (lignocellulosic) is controlled by the susceptibility of these materials to abiotic and biotic degradation processes or imposed physical processes (i.e., indiscriminate disposal practices and subsidence control that lead to loss of containment integrity). The extensive application of imposed physical processes reduces the significance of the containment feature for waste disposed in wood and cardboard containers. However, subsurface conditions at Hanford suggest that some containment materials such as concrete and steel would be relatively stable over time (i.e., thousands to tens of thousands of years), and, therefore, important features to consider in modeling contaminant release from such systems in long-term assessments. Exceptions to this rule would be where reaction of the waste with containment materials (e.g., high-level waste in tanks) would lead to acceleration of the containment degradation process.

Pore water migrating down through the engineered system will contact and react with fill materials (e.g., basalt, grout), containment materials in various states of degradation, and different types of waste. Reaction with these materials will result in changes to the chemistry of the pore water. The chemical 
composition, $\mathrm{pH}$, and redox state of the pore water at any given time will influence the dominant process(es) controlling contaminant release and rates of release from the waste to the migrating pore water.

Release of contaminants from waste to migrating pore water is influenced by specific waste features. Important features include waste stability or ability to maintain structural integrity; structural and compositional makeup of the waste (i.e., the degree of homogeneity or heterogeneity), number, type, concentration of contaminants and permeability. Processes that influence release from the waste to the migrating pore fluid include desorption, diffusion (e.g., diffusion out of permeable waste such as sludge or grout), solubility, solid phase dissolution/precipitation, dissolution, chemical affinity, and corrosion.

Pore water containing contaminants released from the waste (leachate) eventually reaches the engineered system boundary. At the boundary, a leachate collection system, a geomembrane liner, and a synthetic clay liner are the final barriers encountered to the release of contaminants from the engineered system to the vadose zone. Collected leachate moves into a sump where it is removed from the engineered system. For an optimized system, migration of the contaminated pore water is controlled by the low hydraulic conductivity properties of the geomembrane liner and the effective diffusion of contaminants through the geomembrane materials (e.g., diffusion in the pore-water moderated by sorption). Leakage in the geomembrane liner component of such systems is known to occur, often during their installation and predominantly at seams. Under these conditions, migration of contaminants that pass through these breaches is then controlled by restricted migration in the geosynthetic clay layer. 


\subsection{Release Models Described in Previous Assessments and Reviews}

Table 3.1 provides links to specific pages, tables, and figures in publications about release model capabilities relevant to, or that have been applied in, specific Hanford assessments since 1987. The table includes only primary references to available information. The user can search for additional data by referring to publications cited in these documents. Brief summaries of information found in these sources are provided in the following paragraphs.

Table 3.1. Sources of Information on Release Models and Data Relevant to Hanford Assessments

\begin{tabular}{||c|l||}
\hline \multicolumn{1}{|c|}{ Subject } & \multicolumn{1}{|c||}{ Specific Location Within a Reference } \\
\hline \hline Release Models for Subsurface Sources & DOE 1987, Appendix P \\
\hline Release Models for Specific Waste Forms & DOE 1987, Appendix P, p. P.10 \\
\hline Saltcake and Sludge in Single-Shell Tanks & DOE 1987, Appendix P, p. P.11 \\
\hline Liquid Release Scenario for Double-Shell Tanks & DOE 1987, Appendix P, p. P.15 \\
\hline Release from Grout in Vaults & DOE 1987, Appendix P, p. P.17 \\
\hline $\begin{array}{l}\text { TRU-Contaminated Unsaturated Zone Soil in the } \\
\text { 200 Areas }\end{array}$ & DOE 1987, Appendix P, p. P.19 \\
\hline $\begin{array}{l}\text { Source-Release Data for Specific Waste Forms } \\
\text { Discussion of Source-Release Models Used on 200 Area } \\
\text { Plateau Composite Analysis }\end{array}$ & DOE 1987, Appendix P, pp. P.37-P.41 \\
\hline Hanford Composite Analysis Source-Term Release Models & Kincaid et al. 1998, Appendix D \\
\hline $\begin{array}{l}\text { Contaminant Release Models } \\
\text { Equations Used for Soil-Debris Waste Form Type }\end{array}$ & Kincaid et al. 1998, Appendix D, pp. D.3-D.26 \\
\hline Equations Used for the Cake Waste Form Type & Kincaid et al. 1998, Appendix D, pp. D.10-D.13 \\
\hline Equations Used for Glass Waste Form Type & Kincaid et al. 1998, Appendix D, pp. D.13-D.15 \\
\hline Equations Used for Cement Waste Form Type & Kincaid et al. 1998, Appendix D, pp. D.15-D.17 \\
\hline Equations Used for the Reactor Block Waste Form Type & Kincaid et al. 1998, Appendix D, pp. D.17-D.18 \\
\hline $\begin{array}{l}\text { Rationale for Choosing Values for Radionuclide-Related } \\
\text { Parameters in the Release Model Equations }\end{array}$ & Kincaid et al. 1998, Appendix D, pp. D.19-D.22 \\
\hline $\begin{array}{l}\text { Composite Analysis Release Model Parameter Data } \\
\text { Radionuclide Solubility Data Based on Speciation } \\
\text { Modeling }\end{array}$ & $\begin{array}{l}\text { Kincaid et al. 1998, Appendix D, pp. D.27-D.29; } \\
\text { Appendix E, pp. E.1-E.28 }\end{array}$ \\
\hline $\begin{array}{l}\text { Distribution Coefficient Data for Selected Radionuclides } \\
\text { Wn Cementitious Materials }\end{array}$ & Krupka and Serne 1998, pp. 1.2-1.3 \\
\hline \hline
\end{tabular}


Table 3.1. ～(contd)

\begin{tabular}{|c|c|}
\hline Subject & Specific Location Within a Reference \\
\hline Extraction $\mathrm{K}_{\mathrm{d}}$ Values from Diffusion and Leaching Data & Krupka and Serne 1998, Appendix E, pp. E.1-E.6 \\
\hline $\begin{array}{l}\text { Source-Term Release (congruent saltcake dissolution release } \\
\text { model) from High-Level Waste Tanks }\end{array}$ & $\begin{array}{l}\text { DOE 1996b, Volume 4, Appendix F, } \\
\text { pp. F-38-F-59 }\end{array}$ \\
\hline $\begin{array}{l}\text { Source-Term Release (congruent glass dissolution model) } \\
\text { from Low-Activity Waste Disposal Facility }\end{array}$ & $\begin{array}{l}\text { DOE 1996b, Volume 4, Appendix F, } \\
\text { pp. F-57-F-58 }\end{array}$ \\
\hline $\begin{array}{l}\text { Residual Waste Source-Term Conceptual Model for High- } \\
\text { Level Waste Tanks }\end{array}$ & DOE 1999, Appendix A, p. A-27 \\
\hline Release concept for contaminant mass in vitrified waste & Kline 1995, p. 12 \\
\hline Refined release concept for contaminant mass in vitrified waste & Kline 1996 , pp. 2-3 \\
\hline $\begin{array}{l}\text { Simulated fractional release rates for sensitivity analysis } \\
\text { scenarios }\end{array}$ & Kline 1996, Figures 6-31, pp. 30-57 \\
\hline $\begin{array}{l}\text { Conceptual Model for Release of Contaminants from ILAW } \\
\text { Disposal Facility }\end{array}$ & Mann et al. 2000 , pp. $25-26$ \\
\hline ILAW Waste Form Release Rate & Mann et al. 2000, pp. $41-43$ \\
\hline $\begin{array}{l}\text { ILAW Waste Form Release and Near-Field Contaminant } \\
\text { Transport }\end{array}$ & Mann et al. 2000, pp. 50-52 \\
\hline Conceptual Model for Dissolution of Silicate Glass & Bacon and McGrail 2001, pp. 1-2 \\
\hline Dissolution Rate Equation for Glass & Bacon and McGrail 2001, p. 13 \\
\hline $\begin{array}{l}\text { Flux Rate Equation for Release of ILAW Glass } \\
\text { Radionuclide Constituents to the Vadose Zone }\end{array}$ & Bacon and McGrail 2001, pp. 16-17. \\
\hline $\begin{array}{l}\text { Release of Contaminants from Low-Activity Waste Disposal } \\
\text { Facility (glass) }\end{array}$ & DOE 1996b, Volume 4, Appendix F, p. F-57 \\
\hline $\begin{array}{l}\text { Overview of Modeling Approach ( } 200 \mathrm{~W} \text { and } 200 \text { East } \\
\text { LLWPA) }\end{array}$ & $\begin{array}{l}\text { Wood et al. 1995a, pp. 3-8-3-10 } \\
\text { Wood et al. 1996, p. 3-10 } \\
\text { Wood et al. 1996, p. 3-12-3-14 }\end{array}$ \\
\hline Source-Term Analysis (release) & $\begin{array}{l}\text { Wood et al. 1995a, pp. 3-10-3-17 } \\
\text { Wood et al. 1996, pp. 3-14-3-18 }\end{array}$ \\
\hline Advection-Dominated Release Model & $\begin{array}{l}\text { Wood et al. 1995a, pp. 3-12-3-13 } \\
\text { Wood et al. 1996, pp. 3-16-3-17 }\end{array}$ \\
\hline Diffusion-Dominated Release Model & $\begin{array}{l}\text { Wood et al. 1995a, pp. 3-13-3-15 } \\
\text { Wood et al. 1996, pp. 3-17-3-18 }\end{array}$ \\
\hline $\begin{array}{l}\text { Solubility-Limited (constant concentration) Release } \\
\text { Model }\end{array}$ & $\begin{array}{l}\text { Wood et al. 1995a, p. 3-15 } \\
\text { Wood et al. 1996, p. 3-17 }\end{array}$ \\
\hline Release Rate Discussion and Curves & $\begin{array}{l}\text { Wood et al. 1995a, pp. 3-18-3-27 } \\
\text { Wood et al. 1996, pp. 4-10-4-12 }\end{array}$ \\
\hline Release Rate (advection-dominated) & $\begin{array}{l}\text { Wood et al. 1995a, p. 4-22 } \\
\text { Wood et al. 1996, p. F4-5 }\end{array}$ \\
\hline Release Rate (advection dominated) & $\begin{array}{l}\text { Wood et al. 1995a, p. 4-25 } \\
\text { Wood et al. 1996, p. F4-6 }\end{array}$ \\
\hline
\end{tabular}


Table 3.1. ～(contd)

\begin{tabular}{|c|c|}
\hline Subject & Specific Location Within a Reference \\
\hline Release Rate (diffusion-dominated) & $\begin{array}{l}\text { Wood et al. 1995a, p. 4-27 } \\
\text { Wood et al. 1996, p. F4-7 }\end{array}$ \\
\hline Release Summary Results & Wood et al. 1995a, Appendix D, pp. D-11-D-17 \\
\hline $\begin{array}{l}\text { Selected Solubility and Sorption Data Useful to Release } \\
\text { Models }\end{array}$ & Wood et al. 1995a, Appendix E, pp. E-3-E-10 \\
\hline Waste Form Release Analysis and Data Collection & Wood et al. 1995a, Appendix F, pp. F-3-F-10 \\
\hline Description of Release of Carbon-14 in Activated Metal & Wood et al. 1995a, Appendix F, pp. F-3-F-4 \\
\hline $\begin{array}{l}\text { Iodine Release Characteristics from Grout Waste Forms } \\
\text { Under Partially Saturated Conditions }\end{array}$ & Wood et al. 1995a, Appendix F, pp. F-4-F-10 \\
\hline $\begin{array}{l}\text { Overview of Conceptual Model of release of Radionuclides } \\
\text { from ERDF }\end{array}$ & Wood et al. 1995b, pp. 3-6-3-8 \\
\hline $\begin{array}{l}\text { Conceptual model of source term release for ERDF } \\
\text { performance assessment }\end{array}$ & Wood et al. 1995 b, pp. 3-10-3-11 \\
\hline $\begin{array}{l}\text { Mathematical simulation of radionuclide release mechanisms } \\
\text { for ERDF performance assessment }\end{array}$ & Wood et al. $1995 b$, pp. 3.11-3-14 \\
\hline $\begin{array}{l}\text { Source term analysis of base case conditions for ERDF } \\
\text { performance assessment }\end{array}$ & Wood et al. 1995b, pp. 4-8-4-9 \\
\hline $\begin{array}{l}\text { Release model profiles generated in ERDF performance } \\
\text { assessment }\end{array}$ & $\begin{array}{l}\text { Wood et al. 1995b, figure 4-4 (p. 4-38), } \\
\text { figure 4-5 (p. 4-39), figure 4-6 (p. 4-40) }\end{array}$ \\
\hline $\begin{array}{l}\text { Waste Configuration and Contaminant Release Scenarios } \\
\text { (stored transuranic waste) }\end{array}$ & Buck et al. 1996 , pp. $6.1-6.8$ \\
\hline Contaminant Release Scenarios & Buck et al. 1996, pp. 6.5-6.8 \\
\hline Release from Soil-Debris Waste & Buck et al. 1996, pp. 6.5-6.8 \\
\hline Release from Cemented Waste Forms & Buck et al. 1996, p. 6.8 \\
\hline Geochemical Controls on Waste Form Leaching & Buck et al. 1996, p. 6.8 \\
\hline Example Contaminant-Release Calculations & Buck et al. 1996, pp. 6.12-6.15 \\
\hline Contaminant Property Data Useful to Release Models & Buck et al. 1996, Appendix B, pp. B.1-B.18 \\
\hline Conceptual Model for Contaminant Release from ERDF & DOE 1994, pp. 4-1-4-2 \\
\hline $\begin{array}{l}\text { Constituent-Specific Parameters Important to Release } \\
\text { Modeling }\left(\mathrm{K}_{\mathrm{d}} \text {, solubility and decay }\right)\end{array}$ & DOE 1994, pp. 4.4-4.6 \\
\hline Parameter Data to Release Modeling for ERDF & DOE 1994, Tables 4-1 to 4-8, pp. 4T-1-4T-8b \\
\hline $\begin{array}{l}\text { Release Models Used for ERDF Assessment (untreated } \\
\text { waste) }\end{array}$ & DOE 1994, Appendix A, pp. A-2-A-3 \\
\hline $\begin{array}{l}\text { Release Models Used for ERDF Assessment (grouted or } \\
\text { vitrified waste) }\end{array}$ & WHC 1993 \\
\hline $\begin{array}{l}\text { Model Formulations for Contaminant Release from ERDF } \\
\text { Untreated and Treated Waste }\end{array}$ & Roeck 1993, pp. 2-3-2-7 \\
\hline $\begin{array}{l}\text { Model Formulation for Contaminant Travel Time through } \\
\text { Liner }\end{array}$ & Roeck 1993, p. 2-7 \\
\hline
\end{tabular}


Table 3.1. ～(contd)

\begin{tabular}{|c|c|}
\hline Subject & Specific Location Within a Reference \\
\hline Waste Release Parameters & Roeck 1993, pp. 3-5-3-9 \\
\hline Contaminant Specific Parameters & Roeck 1993, p. 3T-4 \\
\hline Probability Distributions for Input Parameters & Roeck 1993, Appendix B \\
\hline Release Model for U.S. Ecology Site Assessment & Dunkelman 2000, Section 1.0, p. 3 \\
\hline $\begin{array}{l}\text { Release of Contaminants from Remediated Waste Sites } \\
\text { (RESRAD model) }\end{array}$ & Yu et al. 1993, Appendix E \\
\hline Sorption-Desorption, Ion Exchange Leaching Model & Yu et al. 1993, Appendix E, pp. 197-201 \\
\hline $\begin{array}{l}\text { Parameters/Data }\left(\mathrm{K}_{\mathrm{d}} \mathrm{s}\right) \text { to Support Leach Model } \\
\text { Component of RESRAD }\end{array}$ & Yu et al. 1993, Appendix E, pp. 201-206 \\
\hline $\begin{array}{l}\text { Estimation of the Distribution Coefficient on the Basis of the } \\
\text { Solubility Constant }\end{array}$ & Yu et al. 1993, Appendix J \\
\hline $\begin{array}{l}\text { Conceptual Model for Release of Contaminants from Grout } \\
\text { Disposal Facility }\end{array}$ & $\begin{array}{l}\text { Kincaid et al. } 1995 \text { a, Figure } 3.1, \text { p. 3.2, p. 3.6, } \\
\text { p. 3.12, p. } 3.16\end{array}$ \\
\hline Release from Grout Source-Term & Kincaid et al. $1995 \mathrm{a}$, p. 3.28 \\
\hline Initial Release Model for Grout & Kincaid et al. 1995a, p. 3.33-3.38 \\
\hline Flow and Transport Properties of the Concrete Vault & Kincaid et al. $1995 \mathrm{a}$, p. $3.39-3.42$ \\
\hline Degradation of Source-Term and Vault Materials & Kincaid et al. 1995a, p. 3.41-3.53 \\
\hline Initial release model for grout (additional details of data) & Kincaid et al. 1995b, Appendix P, pp. P.20-P.29 \\
\hline $\begin{array}{l}\text { Waste Forms (graphite and shielding) and Release Rates from } \\
\text { Surplus Production Reactors }\end{array}$ & DOE 1989, Appendix C, pp. C.2-C.5 \\
\hline $\begin{array}{l}\text { Release Model Options for Surplus Production Reactor } \\
\text { Source-Term }\end{array}$ & DOE 1989, Appendix C, p. C.13 \\
\hline $\begin{array}{l}\text { Release Rates of Radionuclides from Surplus Production } \\
\text { Reactor Source-Term Materials }\end{array}$ & DOE 1989, Appendix D \\
\hline $\begin{array}{l}\text { Leaching of Irradiated Graphite and Fractional Release } \\
\text { Rates }\end{array}$ & White et al. 1984, pp. 42-61 \\
\hline Corrosion Performance of Nuclear Reactor Compartment Steel & DOE 1996c, pp. 4-12-4-16 \\
\hline Release of Lead from Reactor Compartments & DOE $1996 \mathrm{c}$, p. $4-28$ \\
\hline Release of PCB from Reactor Compartments & DOE 1996c, pp. 4-31-4-32 \\
\hline Release and Migration of Lead through Soil & Rhoads et al. 1992, p. vi, 4.18, 4.28 \\
\hline $\begin{array}{l}\text { Estimation of Nickel Release at Reactor Compartment } \\
\text { Burial Ground }\end{array}$ & Rhoads et al. 1994, pp. iii, vi, vii, 4.33 \\
\hline $\begin{array}{l}\text { Estimation of Nickel Corrosion Products in Hanford } \\
\text { Groundwater }\end{array}$ & Rhoads et al. 1994, pp. iii, vi, vii and 3.20 \\
\hline Review of Conceptual Release Models & Serne and Wood 1990, pp. 2.1-2.9 \\
\hline Release Models Used in Hanford Performance Assessments & Serne and Wood 1990, pp. 2.9-2.26 \\
\hline
\end{tabular}


Table 3.1. $\quad$ (contd)

\begin{tabular}{|c|c|}
\hline Subject & Specific Location Within a Reference \\
\hline Release rate from ILAW waste form & Mann et al. 1998 , p. 3-8. \\
\hline Contaminant Release Scenario for ILAW Waste & Mann et al. 1998 , pp. 3-20-3-21 \\
\hline Waste Form Radionuclide Release Rate for ILAW Waste & Mann et al. 1998, pp. 3.38-3-41 \\
\hline $\begin{array}{l}\text { Conceptual, Implementation and Numerical Models of the } \\
\text { Release Module of the System Assessment Capability }\end{array}$ & Bryce et al. 2002, pp. 59-69 \\
\hline $\begin{array}{l}\text { User Instructions for the Systems Assessment Capability, } \\
\text { Rev. } 0 \text { Release Computer Code }\end{array}$ & Eslinger et al. 2002, pp. 115-160 \\
\hline $\begin{array}{l}\text { Discussion of Release Models (Soil-Debris and Cement) Used } \\
\text { in Conduct of } 2002 \text { Hanford Site Solid Waste EIS }\end{array}$ & DOE 2002, Appendix G, pp. G.10-G.18. \\
\hline $\begin{array}{l}\text { EIS }=\text { Environmental impact statement. } \\
\text { ERDF }=\text { Environmental Restoration Disposal Facility. } \\
\text { ILAW }=\text { Immobilized low-activity waste. } \\
\text { LLWPA }=\text { Low-level waste performance assessment. } \\
\text { TRU }=\text { Transuranic (waste) }\end{array}$ & \\
\hline
\end{tabular}

Models were evaluated in the Hanford high-level defense waste environmental impact statement (HDWEIS) (DOE 1987) for use in simulating the release of contaminants from waste forms that might be disposed of in the Central Plateau on the Hanford Site. Release models consisted of four types:

adsorption-controlled release, solubility-controlled release, linear release, and diffusion controlled release. For adsorption-controlled release, release was governed by the retardation factor and concentration of individual radionuclides in the solid phase. For solubility-controlled release, radionuclides were carried away from their source at their maximum solution concentration (i.e., the application of radionuclidespecific solubilities based on the highest radionuclide concentrations found in tank supernate). This release mechanism is an alternative to nitrate salt dissolution and congruent release of radionuclides from the salt (Kincaid et al. 1998, Appendix D). The linear release model was viewed as a model for dissolution-controlled release of a non-decaying chemical (e.g., nitrate). A diffusion-controlled release model was considered applicable when a protective barrier was present, replacing advective transport of contaminants to the containment boundary with diffusion transport of contaminants to the containment boundary. This assumes that the surface barrier (or cover) can be shown to be so effective as to cause diffusion to dominate over advection in the region below the barrier; thus, the release is represented as a diffusion-dominated phenomena. A congruent release of radionuclides and other chemicals is assumed from the waste.

For HDWEIS, model selection was made for specific waste forms, considering both the presence and absence of protective barriers (DOE 1987). For saltcake and sludge in single-shell tanks, without a protective barrier, the solubility model was used for radionuclides and the linear release model was used for non-decaying chemicals. For release of liquid from single-shell tanks, an adsorption model was used. For release of transuranic waste (e.g., in low-level waste burial grounds), adsorption and solubility models were used. In the presence of a protective barrier, a diffusion-controlled model was recommended for two of the above scenarios (salt/sludge, liquid release from tanks), with a decaying source for the radionuclides and a non-decaying source for chemicals. 
Serne and Wood (1990) reviewed conceptual release models (solubility-controlled, diffusioncontrolled, desorption controlled, or fractionally released) as well as models applied to distinct Hanford waste forms and their associated data requirements.

Constant concentration (i.e., empirical solubility-controlled) models have been used in numerous performance assessments. Such models are necessary when identification of the likely controlling solid(s) is difficult. The solubility of a constituent is not a constant value in a chemically dynamic system. However, in empirical solubility models, a controlling solid is assumed and the chemistry of all constituents is fixed to derive a fixed value for the concentration of specific contaminants.

Diffusion-controlled release models are applied to porous solid waste forms (e.g., cemented or grouted waste). The effective diffusion coefficient is calculated from laboratory leach test data and reflects a constituent's retardation in the matrix (i.e., by reaction with the cementitious matrix or adsorption onto matrix additives), as well as the physical hindrance in pores and the tortuosity of the matrix. Release models that use effective diffusion coefficients have been able to effectively predict the results of laboratory leach tests.

Serne and Wood (1990) also describe a desorption-controlled model that contains the attributes of the sorption component of the soil-debris model described in Kincaid et al. (1998). Inherent in the model is the reliance on a linear adsorption isotherm, the requirement of rapid desorption kinetics, the existence of only one type of species for each constituent and one type of sorption site solid matrix.

Empirical release models were described as one of the following: (1) instantaneous release of the entire inventory, (2) constant fraction release (e.g., $1 \%$ of total inventory released per year), (3) constant dissolution or corrosion rate, or (4) congruent release. For congruent release, the major constituent in the waste (e.g., saltcake) controls the release of all other constituents. As the major constituent dissolves, all other constituents within the effected volume are released in their like proportion.

For the Central Plateau composite analysis (Kincaid et al. 1998), five idealized generic types of contaminant source terms (i.e., generic waste forms) were considered for release of radionuclides: soil debris, saltcake/sludge waste, glass waste, cement waste, and reactor block waste. Release was conceptualized to occur as a result of water percolating through a well-mixed waste form, with radionuclides only being lost from the source term via radioactive decay. Releases of contaminants from a soil-debris waste form were proposed to be controlled primarily by partitioning between the aqueous and solid phases. If inventory levels in the waste form were high enough, release was considered to be solubility controlled. For the saltcake waste, release of contaminants was at a constant rate in step with the dissolving of a major structural component of the waste (i.e., nitrate salt in a high-level waste tank). For the glass waste, releases of contaminants occurred congruent with the surface dissolution of the glass. The model took into account changes in dissolution rate as the size of the waste form shrank with time. More advanced models for simulating release of constituents from glass are described in Section 3.2. For cement waste, contaminants inside the waste were assumed to diffuse toward the outer surface, where they were released into the infiltrating water flowing past the waste form. Therefore, release from this source term was controlled by the contaminants' effective diffusion coefficient in the waste. For the reactor block waste, release of contaminants was described by rates calculated from experimental leach test data. 
An initial assessment of Hanford impact performed with the System Assessment Capability (SAC) (Bryce et al. 2002) applied the release model capabilities described in Kincaid et al. (1998) (i.e., liquid, saltcake, soil debris, cement, and reactor block) within the Release Module component of SAC. The Release Module applies release models to waste inventory data from the Inventory Module of SAC and accounts for site remediation activities as a function of time. The resulting releases to the vadose zone, expressed as time-profiles of annual rates, become source terms for the Vadose Zone Module of SAC. Radioactive decay is accounted for in all inputs and outputs of the Release Module. The Release Module is implemented as the VADER (VADose zone Environmental Release) computer code. Details on the structure of the VADER code and instructions on its use can be found in Eslinger et al. (2002).

The recent solid (radioactive and hazardous) waste environmental impact statement applied soildebris and cement models in the evaluation of impacts of low-level burial ground waste on human health and ecological risk at the Hanford Site (DOE 2002, Appendix G). The soil-debris model was used to estimate release of all non-grouted contaminants from previously disposed waste. Waste depths were varied as a function of waste grouping and infiltration rates varied with time (e.g., pre versus post disposal). A barrier design life of 500 years was assumed. For release of uranium, the soil-debris model was run in the solubility-control mode, with a 300-year delay in initiating release to account for the influence of high integrity container containment. The cement model was used for all grouted waste.

Release results (i.e., for technetium-99, iodine-129, and uranium) from the solid waste environmental impact statement and the solid waste burial ground performance assessments (Wood et al. 1995b, 1996) were compared with results from a SAC 10,000-year post-closure assessment (DOE 2002, Appendix L).

There are several key differences in the way these different analyses address selective contaminant releases from the source term. The SAC analysis differs from the other two analyses in the way that uranium is released from low-level waste. For non-cemented waste, the SAC analysis uses a soil-debris model coupled with uranium-specific solubility limits to simulate uranium release. For cemented waste, the SAC analysis uses a cement (that is, diffusion-controlled) release model to simulate uranium release. In contrast, the release of uranium in Hanford solid waste environmental impact statement analysis and the solid waste burial ground performance assessments both rely on a solubility-controlled release model with uranium specific solubility limits depending on whether the uranium inventory is contained in noncemented waste or in cemented waste (for example, $64 \mathrm{mg} / \mathrm{L}$ for non-cemented waste and $0.23 \mathrm{mg} / \mathrm{L}$ for cemented waste).

The SAC application of the cement model to uranium, iodine-129, and technetium-99 releases assumed a cemented waste and a surface-area-to-volume ratio based on a waste volume that constituted a number of aggregated burial ground sites. In contrast, the Hanford solid waste environmental impact statement and the solid waste burial ground performance assessment analyses rely on a conceptualization of surface-area-to-volume ratio based on the surface area and volume of individual waste containers (for example, individual steel barrels, boxes, high integrity containers that would contain grouted waste). As a result, the surface-area-to-volume ratio for the SAC source term was up to 10 times lower than those reported for Hanford solid waste environmental impact statement and the solid waste burial ground performance assessment analyses. A lower release of uranium, iodine-129, and technetium- 99 from the SAC analysis would be expected based on this difference alone. However, when the diffusion coefficient 
is roughly an order of magnitude higher in the SAC application, the lower surface-area-to-volume ratio is partially offset by the higher diffusion coefficient.

From the formulations of the soil-debris model, which is the release model associated with early solid waste disposals at Hanford (that is, pre-1970 waste), it is apparent that the use of larger aggregated areas as opposed to burial ground, trench, or caisson scales to represent waste leads to lower initial concentrations of waste but exposes waste to greater infiltration and, hence, leaching. Use of aggregated representations and the soil-debris model tends to release waste more rapidly than would occur if simulations were conducted on the burial ground or trench scale.

A literature review and calculations have provided technical support to the U.S. Nuclear Regulatory Commission's development of performance assessment methodology for low-level radioactive waste disposal facilities (Krupka and Serne 1998). The U.S. Nuclear Regulatory Commission's source-term model for contaminant release from a low-level waste disposal system requires input from water infiltration and engineered barrier calculations to determine the flux of water that may pass through the disposal unit, contact the waste forms and containers, and possibly lead to release of radionuclides. The source-term model addresses the mechanisms and rates of failure of the waste containers, if the containers are believed to delay the release of any radionuclides. Once the waste containers are breached, it is envisioned that radionuclides are released as a result of chemical reactions that occur when the infiltrating water contacts the waste. These reactions are affected by the composition of the infiltrating water as modified by the chemical environment associated with the waste disposal facility. This environment is envisioned as including cement, metal, and other materials present in the engineered system as well as in the waste, containers, and any backfill materials used in the facility.

The source-term model for low-level waste considers radionuclide release by rinse release, diffusion, or dissolution mechanisms. The rinse-release model assumes quantitative transfer of radionuclides can occur from the waste to the aqueous phase and, therefore, it is the most conservative of the models. It is used when radionuclides are not modeled either with diffusion release (cement solidified waste) or dissolution release (e.g., metallic waste forms). The amount of radionuclide released into the aqueous phase from any of the three source-term models, however, is limited by the thermodynamic equilibrium solubility of the radionuclide. In the real disposal system, it is understood that both chemical factors (e.g., solubility limits, sorption, and dissolution kinetics) and physical factors (e.g., matrix diffusion and limited water contact with the waste) provide constraints on the total amount of radionuclide that can actually be released to water in a facility. The chemistry of the waste form as it ages and the contact of infiltrating water over time with cementitious materials in the engineered system do result in solubility controlling the release of some radionuclides from low-level waste.

The Multimedia Environmental Pollutant Assessment System source-term release formulations include models for estimating contaminant loss from three different types of source zones: contaminated aquifer, contaminated pond/surface impoundment, and contaminated vadose zone (Streile et al. 1996). The models have the capability of partitioning contaminants among multiple phases (e.g., aqueous solution, sorbed to solid particles, in vapor-filled pore space, or in separate non-aqueous phase liquid). The processes considered by the source-term release module are first order decay/degradation, leaching to the vadose zone or groundwater, wind suspension of contaminated surface soil particles, water erosion of contaminated surface soil particles, and volatilization from the source into the atmosphere. 
Other more specific applications of release models are described in the following sections of Chapter 3.

\subsection{Release from High-Level Waste Tanks}

Alternatives were evaluated for the management and disposal of waste in 177 underground storage tanks at the Hanford Site. Release of contaminant inventory from the tanks was determined based on a congruent dissolution model (saltcake) applied following loss of institutional control (100 years). In the model, all constituents in the waste inventory were assumed to be released in proportion to the most abundant material in the waste inventory, nitrate, and at the rate of nitrate dissolution (DOE 1996b). The solubility of nitrate was assumed to be $360 \mathrm{~g} / \mathrm{L}$ (Serne and Wood 1990).

The release of contaminants from tank residuals following retrieval of the high-level waste has been evaluated assuming that the structural integrity of the tanks degrades over time, allowing recharge water to enter the tank, dissolve contaminants from the residuals, and drain out into the surrounding vadose zone through cracks in the tank (DOE 1999). It was assumed that essentially all the drainable liquid waste would be recovered from the tank, eliminating the potential for contaminant release for a period of time following waste retrieval and tank closure. Subsequently, infiltrating water would enter the tank. An enhanced Resource Conservation Recovery Act (RCRA) Subtitle C barrier was assumed to be constructed over the tank farm following waste retrieval and tank stabilization.

The radiological and chemical source term consisted of the inventory of a $1 \%$ residual waste remaining in the tanks after sluicing. The approach to estimating the source term parameters for the residual tank waste assumed that, over time (following closure), the liquid containment integrity of the tanks degraded and the release of contaminants occurred from dissolution by infiltrating water that migrates into and out of the tanks through cracks. This approach was in agreement with the assumed mechanism for contaminant releases from single-shell tanks following closure (Serne and Wood 1990).

A constant concentration release model (analogous to solubility) was used to develop contaminant flux rates based on post-retrieval inventory data ${ }^{1}$. Specific waste type wash factors (Colton 1995, 1996) were assumed to provide representative concentration values for how contaminants would be dissolved in infiltrating water and released over approximately $30 \%$ of the tank base area. This assumption was based on engineering judgment and available data on potential leak mechanisms (WHC 1994b). For tanks in general, the best estimate values for contaminant release rates from the tank residuals were based on the empirical solubility constraints using data that were most directly applicable to the waste type contained in the individual tanks.

\subsection{Release from Immobilized Low-Level Activity Tank Waste}

Past modeling of vitrified waste (from a low-activity waste disposal facility) associated with the tank waste remediation system final environmental impact statement used a glass release model assuming a

\footnotetext{
${ }^{1}$ Letter report COEGMA-98-472 from M. Talbot to K. Hoeft (COEGMA Engineering Corporation), Richland, Washington, Hanford Tanks Initiative - Disposition of Engineering Study Peer Review Comments, dated 1998.
} 
constant corrosion rate for the glass waste form of $3 \times 10^{-6} \mathrm{~cm} /$ year (DOE 1996b). The applicable release model used in this assessment was likely the one described in Kincaid et al. (1998), Appendix D. The release concentration of the contaminants was assumed to be proportional to their concentration in the low-activity glass. Because the total mass loss rate is constant, the composition of the released solution is unaffected by the recharge rate. The source term release is considered overly conservative for many contaminants because solubility controls in groundwater of neutral $\mathrm{pH}$ and relatively high oxidizing conditions would cause contaminants to leach at a rate less than that of nitrate or because the contaminants would be insoluble under these conditions.

Kline (1995) proposed a unit cell model concept in which the waste isolation performance of the vitrified waste facility was evaluated based on simulated performance of a single one of the proposed total number of waste canisters to be emplaced in the facility. Release of contaminants from the waste form was due to the dissolution of the glassified waste by infiltrating moisture and was assumed to be congruent in time with the reduction of small glass spheres of initial radius of $0.25 \mathrm{~cm}$ at a constant rate of $1 \times 10^{-5} \mathrm{~cm} /$ year along the radius. This resulted in an effective release period of 25,000 years. Contaminant concentrations in water inside the source region and contaminant flux out of the source region were determined in part by the availability of contaminant and also by the availability of moisture as the host for diffusive and advective transport.

The unit modeling cell concept was refined and used to simulate the base analysis case and related sensitivity cases for the interim performance assessment of the low-level tank disposal (Kline 1996). The fractional radionuclide release rate from the waste form was assumed to be constant at the maximum value of $1.4 \times 10^{-13} \mathrm{sec}^{-1}\left(4.418 \times 10^{-6} \mathrm{y}^{-1}\right)$. The duration of the constant source term based on the fractional release rate was 226,343.5 years. Based on a constant source volume, a constant volumetric source rate was assumed. A distribution coefficient value of 0 was applied to all radionuclides in the source term resulting in unretarded migration.

The baseline concept for disposal of ILAW at Hanford has been identified as a trench where waste can be remotely handled (Taylor 1999). The existing vaults designed for disposal of grout waste may also be used for disposal of ILAW. The remotely handled trench is a RCRA-compliant landfill (i.e., doublelined trench with leachate collection system) with a surface barrier installed at the time of closure. The remotely handled trench and vault conceptual designs have been described in detail. The total ILAW waste volume is estimated to be $1.581 \times 10^{5} \mathrm{~m}^{3}$ contained in 68,741 waste packages. The composition of the waste is unspecified at this time and will likely change as waste is retrieved from different tanks for vitrification. Data obtained from the testing of glass composition LAWABP1 is being used in current assessments of ILAW (Mann et al. 2000).

The conceptual model for release of contaminants from the ILAW glass waste form and their transfer from the vault to the vadose zone was depicted as follows: (1) infiltration of moisture from precipitation enters the engineered system; (2) the water moves toward the waste form, but most of it is diverted by the disposal system barrier; (3) the water that is not diverted is chemically modified by the local environment and interacts with the metal canisters containing the waste; (4) corrosion of the containers occurs over time; and (5) subsequently, the canisters are breached. 
Water containing corrosion products from the canisters as well as constituents from the surrounding soil interacts with the waste. The waste (silicate glass) corrodes in the following three phases, releasing radionuclides: (1) the glass reacts with water under dilute conditions to release components of the glass into solution; (2) corrosion rates approach a very low constant value as saturated fluid conditions are approached; and (3) secondary mineral phases may form from the saturated fluid resulting (with time) in an acceleration of the forward rate of release. The moisture containing the released contaminants travels downward through the vadose zone until the contaminants reach the unconfined aquifer (Mann et al. 1998).

Dissolution of the waste (glass) along with local chemical conditions is assumed to control the release rate of the radionuclide contaminants. The release rate of the waste is evaluated (based on theoretical considerations) by modeling the basic physical and chemical processes known to control dissolution behavior instead of using empirical extrapolations from laboratory leaching experiments commonly used in other performance assessments. There is no physical constant such as a leach rate or a radionuclide release parameter that can be assigned to a glass waste form in such a dynamic system. This is because both the $\mathrm{pH}$ and composition of the fluid contacting the glass are affected by the flow rate, reactions with other engineered materials, gas-water equilibria, secondary phase precipitation, alkali ion exchange, and dissolution of the glass itself. A general rate equation has been formulated that describes the dissolution of glass as a function of a number of these different parameters (e.g., the amount of moisture, amount of silicic acid, $\mathrm{pH}$, amount of secondary phases) (Mann et al. 2000). The normalized flux to the vadose zone for radionuclides released from the waste packages for the 2001 ILAW performance assessment that incorporates this dissolution concept has recently been described (Bacon and McGrail 2001).

\subsection{Release from Solid Waste Burial Sites}

\subsubsection{Release of Contaminants from Low-Level Waste Burial Grounds}

Release of contaminants from low-level waste cannot be modeled precisely because of the variability of the chemical and physical reactions that occur in the waste material. In the real system, radionuclides and chemicals are distributed in a heterogeneous fashion among different waste materials. Waste package containers fail at different rates because of the variability in waste material, and variable types and quantities of radionuclides and chemicals are dissolved into the infiltrating water over time depending on which waste material contacts a particular volume of water. Therefore, averaging concepts are used in modeling that simplify the mathematical representation of the real system. These concepts must be justified as being a conservative representation of the real system.

Past performance assessments of low-level waste burial grounds (Wood et al. 1995a, 1996) have used three release processes (advection dominated, diffusion dominated, and solubility limited) to address contaminant release from these waste systems. The advection-dominated release model (mixing-cell cascade model, Kovak et al. 1990) was used to simulate the processes of release from unstabilized (not contained) waste. In this case, the entire inventory was immediately available for release. Neither sorption effects nor decay were factored into these calculations. For unstabilized waste, the radionuclides exited the facility at a rate determined by the flow of water and the amount of dispersion (i.e., mixing in the disposal unit, e.g., by near-field transport processes). The diffusion-dominated release model was used to simulate 
the release of contaminants from stabilized, contained wastes. In the absence of convection through the waste container, the release was modeled as a diffusion-limited process. Release from the waste form was represented by a diffusion coefficient. In addition to the diffusion-dominated release of radionuclides from the burial trench, an alternative approach was to specify a solubility or corrosion control limit in the waste form. Infiltration rates of $5 \mathrm{~cm} /$ year were chosen for the category 1 facility and $0.5 \mathrm{~cm} /$ year for the category 3 facility for different modeling scenarios. Category 1 and category 3 waste are distinguished by their radionuclide content, as indicated in DOE (1997).

In the assessment of the 200 West Area burial grounds (Wood et al. 1995a), descriptions were provided for releases of radionuclides (i.e., carbon-14 and iodine-129) from waste forms often found in lowlevel waste burial grounds (e.g., highly shielded containerized waste [activated metal] and grout). Information was also provided from the results of numerical release analyses (Wood et al. 1995a, Appendix D) selected solubility, and sorption data (Wood et al. 1995a, Appendix E), and descriptions of release of carbon-14 from activated metal and iodine from grouted waste forms under partially saturated conditions (Wood et al. 1995a, Appendix F).

The approach to radionuclide release for the groundwater pathway analysis of Hanford's commercial low-level radioactive waste disposal site assumed first order leaching of radionuclides in the waste trench unless the solubility limit of the radionuclide was exceeded. For those instances where the solubility limit was exceeded, a radionuclide concentration equivalent to the radionuclide solubility limit was assumed. A steady state infiltration rate was assumed and no credit was taken for a waste package or waste form (WDOE 2000).

Buck et al. (1996) made an assessment of the consequences of the stabilization of low-level waste at DOE sites (including Hanford) as opposed to their disposal at the Waste Isolation Pilot Plant. Two options were considered: above-ground disposal on an asphalt slab and below-ground disposal on an asphalt slab. When considering the release of contaminants, metal buildings that would contain the waste in the surface disposal scenarios were assumed to degrade quickly (i.e., relative to the 10,000-year evaluation period). For both scenarios, assumptions were also made that the plywood that surrounded and segregated the individual waste packages (metal drums) would degrade rapidly (i.e., relative to the 10,000 -year time frame), along with the metal drums acting as containment for the waste packages ( $<100$ years). The cement waste blocks were assumed to remain intact for the first 500 years and then to catastrophically fail. After the failure, the waste was assumed to act as a porous material.

Five processes were considered for release of the contaminants from these two scenarios: decay, leaching, wind erosion, water erosion, and volatilization. All of these processes were considered in the surface disposal scenario, but leaching and decay were the only processes considered for the buried-waste scenario. Both scenarios were performed without consideration of the presence of a cover and the presence of a concrete or asphalt pad.

The release model formulation for the buried waste scenario was that previously applied in the Central Plateau composite analysis (soil-debris model, Kincaid et al. 1998). The formulation was also modified to accommodate wind and water erosion for application to the surface waste disposal scenario. Release of contaminants from the cement waste blocks was according to the model formulation for release from cement previously applied in the Central Plateau composite analysis (cement model, Kincaid 
et al. 1998), which also accounted for radioactive decay. Infiltrating water percolating through the waste zone was assumed to not penetrate the waste forms. Rather, leaching loss is caused by this water picking up contaminants as they diffuse through the water-filled pores of the cement from the interior to the surface of the waste form. The source-term-release module compares the leaching mass flux calculated by the cement model with the leaching mass flux calculated by the soil-debris model where it is assumed that the waste zone was composed of soil. If the release predicted by soil-desorption control or by solubility control is lower, this value is used for the leaching mass flux.

\subsubsection{Release of Contaminants from the Environmental Restoration Disposal Facility}

Previous modeling for comparing performance assessment/risk assessment of alternative Environmental Restoration Disposal Facility (ERDF) designs considered waste release mechanisms such as contaminant solubility and solid-liquid partitioning that were applied to untreated waste (i.e., contaminated soil) and dissolution and diffusion processes for vitrified waste and grouted waste. In the modeling of treated waste in ERDF (i.e., grout waste) (Roeck 1993), total release of contaminants from the waste was assumed to be the sum of releases derived from (1) dissolution or alteration of the waste matrix with subsequent release of the bound contaminants and (2) diffusion through the pore water to the waste surface where the contaminant subsequently is leached into infiltrating water. It was assumed that advective transport out of the grout waste was negligible. In the case of vitrified waste, release due to diffusional processes was considered zero (virtually no pore water in vitrified waste). Advective transport of contaminants out of vitrified and grouted waste was also considered negligible. Travel time through various liners was also evaluated. It was determined that, given the greater importance of vadose zone travel time, the advantage of accounting for diffusion through the liner was not warranted. Additional reasons given to ignore this mechanism included the computational difficulties in simulating diffusion as a plug flow process and the lack of information regarding constituent-specific diffusion coefficients ${ }^{1}$ (Roeck 1993; DOE 1994).

Wood et al. (1995b) used the same three release processes applied to the low-level waste performance assessments of the 200 West and 200 East Areas ERDF performance assessment. Conservatism was built into source term release estimates; however, the immobilizing properties of activated metal and a grout waste were assumed for some waste streams.

\subsubsection{Release from Remediated High Volume Liquid and Solid Waste Disposal Sites}

The RESRAD model (Gilbert et al. 1989) is used at Hanford to derive cleanup criteria and dose calculations for excavated high-volume liquid and solid waste sites (BHI 1999). The model uses a timedependent leach rate constant calculated from a retardation factor for selected constituents in the contaminated zone to determine a contaminant release rate. Typical average distribution coefficients for various elements in various subsurface materials along with representative values for the physical properties of soils used with this model have been reported (Yu et al. 1993).

\footnotetext{
${ }^{1}$ Internal memo from Westinghouse Hanford Company, Richland, Washington, to F. V. Roeck, Environmental Technology Assessment, dated August 2, 1993.
} 


\subsubsection{Release from Grout Vaults}

Kincaid et al. (1995a) conducted an assessment of the disposal of double-shell tank waste in grout vaults on the Hanford Site. Initial release of contaminants from the grout considered simultaneous, advection, diffusion, and sorption processes. Diffusion was used for those constituents that are controlled by molecular diffusion in the pore solution. Constituents with low solubility or that experience sorption at low concentrations in the pore solution were modeled using sorption/solubility constraints. Diffusion coefficients for specific species were obtained from laboratory leach tests (Serne and Wood 1990; Serne et al. 1992; Martin and Lokken 1992; Lokken 1992; Lokken et al. 1992) and sorption coefficients were calculated from the effective diffusion coefficients. Advection of contaminants from the grout was also assumed as a result of degradation of the engineered system over time.

\subsubsection{Release from Reactor Cores of Production Reactors}

In the reactor block release model, irradiated graphite was assumed to release contaminants (via leaching) into infiltrating water over time. Irradiated metals (e.g., iron and aluminum) were assumed to release contaminants (via corrosion) into the infiltrating water over time. Release of lead (a shielding component in the reactor core system) was based on a solubility-controlled release into the infiltrating water. The reactor block release model was used to simulate release from each of the surplus reactors (DOE 1989). No credit was taken in the analyses for liner or leachate collection systems. For the dosimetric analysis, it was assumed that half of the released carbon-14 and other constituents were transported by the groundwater, and the remainder was assumed to be transported directly out of the burial site into the atmosphere. For the various scenarios, a post-disposal assessment period of 10,000 years was evaluated.

\subsubsection{Release Rates for Graphite}

A release function was developed for carbon-14 release from graphite. (The key reaction was assumed to be carbon reacting with oxygen in the air dissolved in the water.) A rate of $2.2 \times 10^{-12} \mathrm{~g} / \mathrm{cm}^{2} / \mathrm{day}$ was determined (wet storage conditions) (Gray 1982). The resulting release would extend over 23,000 years. White et al. (1984) studied the leaching of carbon-14 from demineralized water and calculated a release rate of $5.5 \times 10^{-7} \mathrm{~cm} /$ day at $22^{\circ} \mathrm{C}$, which is in good agreement with the results of Gray (1982). White et al. (1984) was able to develop an equation to describe the release rates from irradiated graphite in saturated groundwater as a function of time and temperature. Release rates under dry storage conditions were related to release rates under wet storage conditions, based on the relative humidity of the surrounding air. Carbon-14 release rates from irradiated metals are unknown. For activation products in metal components in the reactor block, release rates can be equated with corrosion rates (Sections 3.3.5.2, 3.3.5.3, and 3.3.5.4).

\subsubsection{Release Rates of Radionuclides (other than C-14) from Graphite}

Release rates of radionuclides other than carbon-14 have been reported by White et al. (1984) for chlorine-36, iron-55, cobalt-60, barium-133, cesium-134, europium-154, and tritium. 


\subsubsection{Release Rates from Shielding and Metal Components}

The iron shielding and aluminum components of the reactor contain activation products that are subject to release as corrosion occurs. To provide a release rate for these radionuclides, iron was assumed to corrode at a rate of 5 mils $(0.005 \mathrm{in} . /$ year $)$ or $3.5 \times 10^{-5} \mathrm{~cm} /$ day. Based on this corrosion rate, the radionuclides would release over a period of 390 years (DOE 1989). Aluminum components were assumed to corrode at a rate of $0.1 \mathrm{mil} /$ year, yielding a release rate of $7 \times 10^{-7} \mathrm{~cm} /$ day. Based on this corrosion rate, the radionuclides in the aluminum would release over a period of 1,250 years (DOE 1989).

\subsubsection{Release Rates of Lead from Shielding}

Water was assumed to reach a solubility limited lead concentration of $0.29 \mathrm{mg} / \mathrm{L}$. Lead migration would be very slow. Predicted peak concentrations would not occur for between 4.5 million and 45 million years for disposal in the 200 West Area and between 200,000 and 10 million years for disposal in the 100 Area (DOE 1989).

\subsubsection{Releases of Contaminants from Naval Reactor Compartments}

Radioactivity in the compartments of decommissioned Naval reactors is primarily in the form of corrosion-resistant activated metals (e.g., nickel-63, carbon-14, niobium-94, nickel-59, selenium-79, and technetium-99) that make up the hull and internal structure of the reactor pressure vessel. The Navy estimated that more than $99 \%$ of the inventory is found in these metals (DOE 1996c). Also present within the reactor vessel are polychlorinated biphenyls (PCBs) used for thermal shielding and lead (used for radioactivity shielding). After 500 years, only nickel-63 remains. High-strength carbon steels and veryhigh-tensile strength alloyed steels form the exterior of reactor compartment disposal packages (DOE 1996c).

A previous study (Rhoads et al. 1994) considered the disposal of a group of 120 reactor compartments at a 200 East Area burial ground as a potential source of activated nickel (nickel-59 and nickel-63) to groundwater. The compartments were modeled with average quantities of nickel alloy and activated nickel, based on total inventories found in reactor compartments. Nickel radionuclides were modeled as activated constituents of corrosion resistant steel and steel alloys. Recharge $(0.1,0.5$, and $6 \mathrm{~cm} /$ year) passing through this area was assumed to contact the reactor compartment and exit saturated with nickel. Corrosion rates used were $0.0001 \mathrm{mg} / \mathrm{cm}^{2} /$ year and $0.0002 \mathrm{mg} / \mathrm{cm}^{2} /$ year, respectively, for the different corrosion resistant steels. It was found that nickel-63 would decay to negligible levels $\left(\sim 1 \times 10^{-10}\right.$ picocuries per liter $[\mathrm{pCi} / \mathrm{L}])$ prior to reaching the aquifer, even under the highest levels of recharge simulated (i.e., $6 \mathrm{~cm} / \mathrm{yr})(\mathrm{DOE} 1996 \mathrm{c})$.

In a similar study (Rhoads et al. 1992), the release and migration of lead from the reactor compartments was also estimated. As with nickel, average lead quantities were used. Lead was very conservatively assumed to be immediately available for dissolution, so that all groundwater contacting the $15.2 \mathrm{x}$ $15.2 \mathrm{~m}^{2}$ reactor compartments would exit the area being fully saturated with dissolved lead. Lead solubility was set at roughly double experimental results. 
A solubility-limited concentration of 15 parts per billion (ppb) was used to simulate the release of PCBs from reactor compartments and to assess impacts to the Columbia River. Downstream concentrations of PCBs in the aquifer would be less than $0.5 \mathrm{ppb}$ for the postulated wetter condition and less than $0.1 \mathrm{ppb}$ for the current climate (DOE 1996c).

\subsubsection{Releases of Contaminants from Process Facilities (canyons and tunnels)}

Documented work on release of contaminants from process and storage facilities is unknown. Kincaid et al. (1998) chose to exclude such source terms from the Central Plateau composite analysis based on (1) the absence of data on radionuclide inventories for these facilities and (2) the fact that these facilities appear to retain excellent waste performance characteristics for stabilization of radionuclide contamination. For the latter point, it was assumed that it was unlikely that such facilities would be a significant source of groundwater contamination, especially in the next 1,000 years. One exception to this exclusion was the modeling of the release of cesium-137 and strontium-90 inventories from B Plant and B Plant filters which, under a most conservative release scenario, showed no release of these constituents to the groundwater within 1,500 years. Decommissioned process facilities would consist of waste, both internal and external to entombed concrete structures. Future modeling of contaminant release from such waste sources might consider employing a combination of cement and soil-debris models. 


\subsection{Release Model Mathematical Formulations and Data Sources}

An assessment of the publications identified in Table 4.1 indicated that model formulations used over the past 15 years to simulate contaminant release from some of the more common waste forms have been relatively constant in their depiction. Formulations used in the recent Central Plateau composite analysis (Kincaid et al. 1998) appear to have been commonly used. General descriptions of these models are summarized in the subsections below, along with associated parameter definitions and their units. Analytical solutions for each model are limited to those that describe contaminant release as a function of time and do not include a term for decay $\left(\mathrm{e}^{\mathrm{t} \lambda}\right)$.

Table 4.1. Relationship Between Selected Release Formulations Found in Kincaid et al. (1998) and Those Found or Assumed Used in Other Referenced Sources. A blank cell means no model available for comparison.

\begin{tabular}{|c|c|c|c|c|}
\hline \multirow[b]{2}{*}{ Other Sources } & \multicolumn{4}{|c|}{ Kincaid Listed Release Model Formulations } \\
\hline & Soil-Debris & Saltcake & Cement & Glass \\
\hline $\begin{array}{l}\text { DOE (1987), Equation P.6, p. P.3; Equation P.17, } \\
\text { p. P.4 }\end{array}$ & Same & $\mathrm{N} / \mathrm{A}$ & N/A & $\mathrm{N} / \mathrm{A}$ \\
\hline DOE (1987), Equations P.21 and P.22, p. P.5 & $\mathrm{N} / \mathrm{A}$ & Same & N/A & $\mathrm{N} / \mathrm{A}$ \\
\hline $\begin{array}{l}\text { Roeck (1993), Equation 2-1, p. 2-3 (untreated } \\
\text { waste) }\end{array}$ & Same & $\mathrm{N} / \mathrm{A}$ & & \\
\hline $\begin{array}{l}\text { Roeck (1993), Equations 2-2 through 2-5 (treated } \\
\text { waste) }\end{array}$ & N/A & $\mathrm{N} / \mathrm{A}$ & - (a) & - (a) \\
\hline $\begin{array}{l}\text { Wood et al. (1995a), Equations } 3.5 \text { and } 3.7 \text {, } \\
\text { pp. 3-12-3-13 }\end{array}$ & Same $^{(b)}$ & $\mathrm{N} / \mathrm{A}$ & Same & N/A \\
\hline Wood et al. (1995b) & Same $^{(b)}$ & $\mathrm{N} / \mathrm{A}$ & Same & $\mathrm{N} / \mathrm{A}$ \\
\hline $\begin{array}{l}\text { Wood et al. (1996), Equations } 3.5 \text { and 3.7, } \\
\text { pp. 3-16-3-17 }\end{array}$ & Same $^{(b)}$ & N/A & Same & N/A \\
\hline Buck et al. (1996), Equations 6.3 and 6.5, p. 6.6 & Same & $\mathrm{N} / \mathrm{A}$ & Same $^{(\mathrm{c})}$ & $\mathrm{N} / \mathrm{A}$ \\
\hline Serne and Wood (1990), Equations 1 and 6, p. 2.4 & Same & Same $^{(\mathrm{d})}$ & Same & $\mathrm{N} / \mathrm{A}$ \\
\hline DOE (1996b), Appendix F, p. F-39 & N/A & Same & $\mathrm{N} / \mathrm{A}$ & Same ${ }^{(\mathrm{e})}$ \\
\hline Eslinger et al. (2002), pp. 116-122 & Same & Same & Same & $\mathrm{N} / \mathrm{A}$ \\
\hline Bryce et al. (2002), pp. 66-68 & Same & Same & Same & $\mathrm{N} / \mathrm{A}$ \\
\hline DOE (2002), pp. G.10-G.18 & Same & $\mathrm{N} / \mathrm{A}$ & Same & N/A \\
\hline Mann et al. (1998), Equation 3.9, p. 3-40 & $\mathrm{N} / \mathrm{A}$ & $\mathrm{N} / \mathrm{A}$ & N/A & $\begin{array}{l}\text { Same as Kincaid et al. 1998, } \\
\text { Appendix D, Equation D.5 }\end{array}$ \\
\hline Bacon and McGrail 2001, pp. 16-17 & N/A & N/A & N/A & Not the same \\
\hline \multicolumn{5}{|c|}{$\begin{array}{l}\text { NA = Not applicable. } \\
\text { (a) The total rate of release from vitrified and fixated waste was considered equal to the sum of dissolution and diffusion } \\
\text { release. } \\
\text { (b) The model is called a mixing-cell cascade model and has the same formulation as the soil-debris model with the excep } \\
\text { of the addition of a dispersion term. } \\
\text { (c) Equation } 2.5 \text { of Buck et al. } 1995 \text { factors in the effects of soil erosion. } \\
\text { (d) Serne and Wood (1990), p. } 2.13 \text {, report the use of a congruent release model for release of radionuclides. } \\
\text { (e) DOE 1996b, Appendix F, page F-57, A constant corrosion rate of } 3 \times 10^{-6} \mathrm{~cm} / \text { year was assumed for the glass model. }\end{array}$} \\
\hline
\end{tabular}


Possible applications of the release models to various Hanford waste source terms are summarized in Table 4.2. Assignment of a sub-set of these models to some of these source terms was made in performance of the initial run of the System Assessment Capability (Riley and Lo Presti 2001b).

Table 4.2. Summary of Possible Source-Term Release Model Assignments to Waste Source Types and Associated Assumptions

\begin{tabular}{|c|c|}
\hline Release Model & Waste Source Type \\
\hline Liquid & $\begin{array}{l}\text { Single-shell tank past leaks and future losses, }{ }^{\left({ }^{(a)}\right)} \text { unplanned releases, }{ }^{(\mathrm{b})} \text { trenches },{ }^{\left({ }^{(c)}\right.} \text { cribs, }{ }^{\left({ }^{(c)}\right.} \\
\text { drain/tile fields, }{ }^{(\mathrm{c})} \text { radioactive process sewers, french drains, retention basins, ponds, ditches, } \\
\text { sumps, sand filters, injection/reverse wells, storage tanks, diversion boxes, catch tanks, valve } \\
\text { pits, settling tanks, receiving vaults, neutralization tanks }\end{array}$ \\
\hline Soil-debris & $\begin{array}{l}\text { Unplanned releases }{ }^{(\mathrm{b})} \text { burial grounds, laboratories, storage, stacks, landfills, decommissioned } \\
\text { reactor compartments }{ }^{(\mathrm{d})}\end{array}$ \\
\hline $\begin{array}{l}\text { Solubility/Constant } \\
\text { concentration }\end{array}$ & Same as soil-debris model \\
\hline Cement & Process units or plants, control structures, storage tunnels \\
\hline Saltcake & Single-shell tank ${ }^{(\mathrm{a})}$ and double-shell tank $\mathrm{t}^{(\mathrm{e})}$ residuals \\
\hline Reactor block $^{(\mathrm{f})}$ & Decommissioned surplus production reactors \\
\hline Glass & Vitrified immobilized low-activity tank waste \\
\hline $\begin{array}{l}\text { Naval reactor } \\
\text { compartments }\end{array}$ & Reactor vessels within Naval reactor compartments ${ }^{(\mathrm{g})}$ \\
\hline \multicolumn{2}{|c|}{$\begin{array}{l}\text { Releases from single-shell tanks have been modeled using a combination of liquid and saltcake models. } \\
\text { Releases include past tank leaks, liquid released during retrieval, and contaminant release from dissolution of } \\
\text { residual solids following waste retrieval completion. }\end{array}$} \\
\hline \multicolumn{2}{|c|}{ Modeled as initial liquid release, release from a surface contaminated soil or a combination of both. } \\
\hline \multicolumn{2}{|c|}{$\begin{array}{l}\text { Radionuclides from } 216-Z-1 \mathrm{~A} \text { drain/tile field, } 216-Z-9 \text { trench, and } 216-Z-18 \text { crib are modeled as liquid release. } \\
\text { Carbon tetrachloride from these sites has been modeled as release from entire vadose zone profile using soil } \\
\text { debris model. }\end{array}$} \\
\hline \multicolumn{2}{|c|}{$\begin{array}{l}\text { Several chemicals }\left(\mathrm{Cr}^{+6} \text {, lead, and } \mathrm{PCB}\right) \text { are found in reactor compartments. Following corrosion of the reactor } \\
\text { hull, such constituents would be release based on solubility or sorption controls. }\end{array}$} \\
\hline \multicolumn{2}{|c|}{$\begin{array}{l}\text { Double-shell tanks are assumed not to leak prior to and during retrieval. Release of contaminants from residual } \\
\text { solids modeled using saltcake model. }\end{array}$} \\
\hline \multicolumn{2}{|c|}{$\begin{array}{l}\text { B reactor release occurs entirely in the } 100 \text { Area. Following a specified period of time ( } 75 \text { years) remaining } \\
\text { inventories for all other reactors moved to } 200 \text { West Area burial ground }(218-\mathrm{W}-5) \text { where release continues } \\
\text { using the reactor block model. }\end{array}$} \\
\hline \multicolumn{2}{|c|}{$\begin{array}{l}\text { Radionuclides present in steel of reactor vessels would be released to the infiltrating water corrosive breach of } \\
\text { the reactor hull. }\end{array}$} \\
\hline
\end{tabular}

Table 4.3 summarizes the key parameters for the release models and refers the user to tables appearing below in this report that link the user to the relevant source documents for each model and parameter. In the discussion that follows, the user is provided a brief description of information associated with each table along with any important points that need to be noted regarding parameter or data applications to specific release models. 
Table 4.3. Parameters and Data Sources for Release Models ${ }^{(a)}$

\begin{tabular}{|c|c|c|c|c|c|c|c|}
\hline \multirow[b]{2}{*}{ Model Parameter } & \multicolumn{7}{|c|}{ Release Model Type } \\
\hline & Liquid & Soil-Debris & Saltcake & Cement & $\begin{array}{l}\text { Reactor } \\
\text { Block }\end{array}$ & Glass & Corrosion $^{(\mathrm{b})}$ \\
\hline Cross sectional area of source zone & & Table 4.7 & Table 4.7 & & & & \\
\hline Depth of waste & & Table 4.7 & & & & & \\
\hline Distribution coefficient & & Table 4.4 & & & & & \\
\hline Bulk density & & Table 4.5 & & & & & \\
\hline Volumetric moisture content & & Table 4.5 & & & & & \\
\hline Solubility & & Table 4.6 & Table 4.10 & & & & \\
\hline Fractional release & $\mathrm{X}$ & & & & Table 4.12 & Table 4.13 & Table 4.14 \\
\hline Recharge rate & & Table 48 & Table 4.8 & & & & \\
\hline Tank solid waste density & & & Table 4.10 & & & & \\
\hline Waste surface area & & & & Table 4.7 & & Table 47 & Table 4.7 \\
\hline Waste volume & & & & Table 4.7 & & Table 47 & \\
\hline Diffusion coefficient & & & & Table 4.11 & & & \\
\hline Dissolution rate & & & & Table 4.11 & & Table 4.13 & \\
\hline Corrosion rate & & & & & & & Table 4.14 \\
\hline $\begin{array}{l}\text { Mass of structural component in } \\
\text { source zone }\end{array}$ & & & $\mathrm{X}$ & & & & $\mathrm{X}$ \\
\hline Mass or activity of contaminant & $\mathrm{X}$ & $\mathrm{X}$ & $\mathrm{X}$ & $\mathrm{X}$ & $\mathrm{X}$ & $\mathrm{X}$ & $\mathrm{X}$ \\
\hline Temperature & & & & & Table 4.12 & & \\
\hline $\begin{array}{l}\text { Distance from soil surface to bottom } \\
\text { of contaminant source zone }\end{array}$ & & Table 4.7 & & & & & \\
\hline Water erosion rate & & Table 4.9 & & & & & \\
\hline Wind suspension rate & & Table 4.9 & & & & & \\
\hline Dispersion coefficient & & Table 4.9 & & & & & \\
\hline $\begin{array}{l}\text { (a) Fields marked with an X indicat } \\
\text { source of such information woul } \\
\text { (b) Model developed from informat }\end{array}$ & $\begin{array}{l}\text { ormation } \\
\text { the Sys } \\
\text { in Rhoad }\end{array}$ & $\begin{array}{l}\text { it is required } \\
\text { Assessment C } \\
\text { al. 1994, pp. }\end{array}$ & $\begin{array}{l}\text { the specifie } \\
\text { pability (SA } \\
\text { and } 4.2 \text {. }\end{array}$ & $\begin{array}{l}\text { lease mode } \\
\text { inventory da }\end{array}$ & $\begin{array}{l}t \text { is not docu } \\
\text { ase. }\end{array}$ & nted in this & ort. A key \\
\hline
\end{tabular}

\subsection{Liquid Release Model}

Liquid releases are modeled as being dumped to the ground and instantly available to go into the vadose zone without retardation the year they enter the inventory (Eslinger et al. 2002). This is a passthrough, no decay, instantaneous release and complete depletion release model. The loss of contaminant from the waste source as a function of time is given by:

$$
d M / d t=M F
$$

where: $\quad \mathrm{M}=$ the current quantity of contaminant in the source zone $(\mathrm{Ci}$ or $\mathrm{kg})$

$$
\mathrm{F}=\text { the fractional release rate }\left(\mathrm{y}^{-1}\right)
$$


When the fractional release rate is assigned the value of 1 , the entire contaminant mass is instantaneously released into the ground. The dumping of the contaminant mass can be retarded by assigning a fractional release rate between 0 and 1 .

\subsection{Soil-Debris Model}

\subsubsection{Mathematical Formulations for Soil-Debris Model}

The rate of loss of contaminant for a given contaminant by the soil-debris model is given by:

$$
d M / d t=-Q_{w} A C_{w}
$$

(Equation D.35, p. D.11, Kincaid et al. 1998)

where $C_{w}=C_{s o l}$ in Equation D.35 when the release process is solubility-controlled and $C w=M /(\theta R A h)$ in Equation D. 35 when the release process is desorption-controlled where:

$$
R=1+\left(\beta K_{d}\right) / \theta
$$

Switching régimes is controlled by comparing the remaining mass with the maximum mass $\mathrm{M}_{\max }$ consistent with an aqueous phase saturated with the contaminant. If $\mathrm{M}$, the mass remaining in the waste form is larger than the quantity $\mathrm{M}_{\max }$ where:

$$
M_{\max }=\theta R C_{\text {sol }} A h
$$

the release process is considered to be solubility controlled; otherwise it is desorption controlled

where: $\mathrm{M}_{\max }=$ the maximum amount of contaminant possible in the source zone (in Ci or $\mathrm{kg}$ ) without a precipitated phase

$\mathrm{M}=\mathrm{M}(\mathrm{t})$ is current quantity of contaminant contained in the source zone (Ci or $\mathrm{kg})$

$\mathrm{Q}_{\mathrm{w}}=$ recharge rate for the site in $\mathrm{cm} /$ year. $\mathrm{Q}_{\mathrm{w}}$ can be considered constant, or it can be timedependent based on site climate and remediation activities

$\mathrm{A}=$ surface area of the soil waste form exposed to the release mechanism $\left(\mathrm{cm}^{2}\right)$

$\mathrm{h}=$ depth of the waste form in the site $(\mathrm{cm})$

$\mathrm{C}_{\mathrm{w}}=$ a coefficient expressing the effective release of the contaminant $\left(\mathrm{Ci} / \mathrm{cm}^{3}\right.$ or $\left.\mathrm{kg} / \mathrm{cm}^{3}\right)$

$\mathrm{C}_{\mathrm{sol}}=$ expresses aqueous solubility of the contaminant in $\mathrm{Ci} / \mathrm{cm}^{3}$ or $\mathrm{kg} / \mathrm{cm}^{3}$

$\mathrm{R}=$ either a retardation factor or a soil apportionment factor (unitless) which depends on several factors:

- B Soil bulk density in $\mathrm{g} / \mathrm{cm}^{3}$

- $\mathrm{K}_{\mathrm{d}}$ Sorption factor $\left(\mathrm{cm}^{3} / \mathrm{g}\right)$

- $\theta$ Soil volumetric content of water in soil (unitless fraction)

$\mathrm{dM} / \mathrm{dt}=$ the rate of loss of contaminant from the source zone (the rate contaminant crosses the soil waste form boundary and enters the environment)

$\mathrm{t}=$ the elapsed time (years) from the beginning of release from containment 
Buck et al. (1996) took into account the effects of water erosion and wind suspension on contaminant release to the vadose zone from burial ground wastes. For this case, the soil debris equation takes the form:

$$
d M / d t=-Q_{w} M / \theta_{w} R\left[h_{o}-(E+S) t\right]
$$

where: $h_{\mathrm{o}}=$ the initial distance from the soil surface to the bottom of the contaminant-source zone $(\mathrm{cm})$

$\mathrm{E}=$ the volumetric rate of soil removal by water erosion, per area $(\mathrm{cm} /$ year $)$

$\mathrm{S}=$ the volumetric rate of soil removal by wind suspension, per area $(\mathrm{cm} /$ year $)$

\subsubsection{Sources of Data for Soil-Debris Model}

Sources of data for the soil-debris model are provided in the text and in Tables 4.4 through 4.9.

\subsubsection{Distribution Coefficients for Soil-Debris Model}

Table 4.4 summarizes distribution coefficient data potentially applicable to the soil-debris model. Since application of the model is to the near field, recent efforts have focused on using values in the model that reflect a specific waste type and waste zone (high impact) (Riley and Lo Presti 2001b) as initially developed for the 200 Area plateau composite analysis (Kincaid et al. 1998). In many cases, particularly with organic constituents, such specificity is not available. In such cases, distribution coefficient values applied to vadose zone or groundwater modeling may also be applied to the release model.

Table 4.4. Sources of Distribution Coefficient $\left(\mathrm{K}_{\mathrm{d}}\right)$ Data for Soil-Debris Model

\begin{tabular}{||l|l||}
\hline \multicolumn{1}{|c||}{ Information Source Summary } & \multicolumn{1}{|c||}{ Reference } \\
\hline \hline $\begin{array}{l}\text { Distribution coefficients for the soil-debris model as applied to the } \\
\text { System Assessment Capability initial run (SAC Rev. 0) are found } \\
\text { here. Those applied were those for the high impact zone for six source } \\
\text { categories as defined in Kincaid et al. (1998), Appendix E, Table E.4. }\end{array}$ & Riley and Lo Presti 2001b \\
\hline $\begin{array}{l}\text { Definitions of and the rationale for development of zone categories } \\
\text { and source categories for } \mathrm{K}_{\mathrm{d}} \text { values are provided. Conservative, best } \\
\text { estimate, and range estimates of } \mathrm{K}_{\mathrm{d}} \text { 's for different radionuclides are } \\
\text { provided that were used in the 200 Area plateau composite analysis. } \\
\text { Relevant } \mathrm{K}_{\mathrm{d}} \text { 's for release are the high impact zone category for the six } \\
\text { source categories. }\end{array}$ & $\begin{array}{l}\text { Kincaid et al. 1998), Appendix E, } \\
\text { Tables E.2 through E.17 }\end{array}$ \\
\hline $\begin{array}{l}\text { Partition coefficients used in a screening performance/risk assessment } \\
\text { of ERDF }\end{array}$ & Roeck 1993, pp. 3-7-3-8; Table 3-4 \\
\hline $\begin{array}{l}\text { Probability distributions for values of } \mathrm{K}_{\mathrm{d}} \text { for constituents of concern in } \\
\text { the ERDF screening performance/risk assessment }\end{array}$ & Roeck 1993, Appendix B, p. B-8 \\
\hline $\begin{array}{l}\mathrm{K}_{\mathrm{d}} \text { values used in a fate and transport model to predict groundwater } \\
\text { concentrations at the ERDF boundary. } \mathrm{K}_{\mathrm{d}} \text { values were calculated to be } \\
\mathrm{K}_{\mathrm{oc}} \mathrm{X} \text { 0.001 organic content for organic constituents. }\end{array}$ & DOE 1994, Tables 4-2, 4-3, and 4-4 \\
\hline $\begin{array}{l}\mathrm{K}_{\mathrm{d}} \text { values used in the release source term for the Waste Isolation Pilot } \\
\text { Plant no-action alternative }\end{array}$ & Buck et al. 1996, Appendix B, Table B.3 \\
\hline
\end{tabular}


Table 4.4. (contd)

\begin{tabular}{||l|l||}
\hline \multicolumn{1}{|c||}{ Information Source Summary } & \multicolumn{1}{|c||}{ Reference } \\
\hline \hline $\begin{array}{l}\text { Retardation factor for advection-dominated release model set to 1 for } \\
\text { disposal units for the 200 West and East Area performance } \\
\text { assessments }\end{array}$ & $\begin{array}{l}\text { Wood et al. 1995a, p. 3-12 } \\
\text { Wood et al. 1996, p. 3-16 }\end{array}$ \\
\hline $\begin{array}{l}\text { Preferred distribution coefficients for selected radionuclides for } \\
\text { cement/concrete environments }\end{array}$ & Krupka and Serne 1998, p. 5.8 \\
\hline $\begin{array}{l}\text { Desorption }\left(\mathrm{R}_{\mathrm{d}}\right) \text { values for contaminant release from soils and solid } \\
\text { wastes }\end{array}$ & $\begin{array}{l}\text { Serne and Wood 1990, Appendix A, } \\
\text { Table A.3 }\end{array}$ \\
\hline $\begin{array}{l}\text { Distribution coefficients for desorption-controlled release from } \\
\text { contaminated soil }\end{array}$ & Serne and Wood 1990, Table 6, p. 2.25 \\
\hline $\begin{array}{l}\text { Distribution coefficients for selected metals and radionuclides used in } \\
\text { the RESRAD model }\end{array}$ & Yu et al. 1993, pp. 202-205 \\
\hline $\begin{array}{l}\text { Rd values for use in contact with soil } \\
\text { Source of } \mathrm{K}_{\mathrm{d}} \text { values measured with Hanford sediment for } \\
\text { radionuclides and toxic compounds that have the greatest potential for } \\
\text { driving risk to human health and safety in the vadose zone and } \\
\text { groundwater at the Hanford Site }\end{array}$ & $\begin{array}{l}\text { Kincaid et al. 1995b, Appendix P, } \\
\text { pp. P.24-P.29 }\end{array}$ \\
\hline $\begin{array}{l}\mathrm{K}_{\mathrm{d}} \text { values selected for modeling release of radionuclides from waste in } \\
\text { U.S. Ecology trenches }\end{array}$ & $\begin{array}{l}\text { Dunkelman 2000, Section 3.0, p. 6, } \\
\text { Table 7, p. 33 }\end{array}$ \\
\hline $\begin{array}{l}\mathrm{K}_{\mathrm{d}} \text { values used in groundwater pathway analysis of U.S. ecology low- } \\
\text { level waste disposal site }\end{array}$ & Rood 2000, p. 7 \\
\hline $\begin{array}{l}\mathrm{K}_{\mathrm{d}} \text { values used in a comparative groundwater pathway analysis of low- } \\
\text { level waste burial grounds }\end{array}$ & $\begin{array}{l}\text { DOE 2002, Appendix L, Table L.2, } \\
\text { p. L.19. }\end{array}$ \\
\hline $\begin{array}{l}\mathrm{K}_{\mathrm{d}} \text { values for contaminants as a function of mobility class } \\
\text { DOE 2002, Appendix G, Table G.1, } \\
\text { pp. G.9-G.11 }\end{array}$ \\
\hline ERDF = Environmental Restoration Disposal Facility. & \\
\hline \hline
\end{tabular}

\subsubsection{Bulk Density and Moisture Content Data for Soil-Debris Model}

Table 4.5 summarizes sources of bulk density and moisture content data for the soil-debris model.

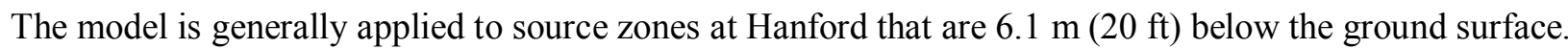
The greatest amount of data for bulk density and moisture content $6.1 \mathrm{~m}(20 \mathrm{ft})$ below the surface is found for 200 East Area soils (Fayer et al. 1999). Considerably less data is found for soil in the 100 and 300 Areas (Peterson et al. 1996; Schalla et al. 1988). No source of such data has been found for 200 West Area soil. Most recently, data from these sources were used to calculate bulk density and volumetric moisture content values as a function of depth for the 100, 200 West, 200 East, and 300 Areas for application to waste sources using the soil-debris model for the initial run of the system assessment capability (Riley and Lo Presti 2001b). Some of the data in Table 3.5 is documented as percent moisture. The parameter in the model requires volumetric moisture content, which can be calculated knowing the percent moisture and the bulk density of the soil (volumetric moisture content $=$ vol. of water in sample divided by ([dry wt of soil/bulk density] + vol. of water). 
Table 4.5. Sources of Bulk Density and Moisture Content Data for Soil-Debris Model

\begin{tabular}{||l|l||}
\hline \multicolumn{1}{|c||}{ Information Source Summary } & \multicolumn{1}{|c||}{ Reference } \\
\hline \hline $\begin{array}{l}\text { Bulk density and volumetric moisture content data for the soil-debris } \\
\text { model as applied to the System Assessment Capability initial run } \\
\text { (SAC Rev. 0) are found here. Data were calculated from some of the } \\
\text { sources described below }\end{array}$ & Riley and Lo Presti 2001b \\
\hline $\begin{array}{l}\text { Volumetric moisture content and bulk density distributions for } \\
\text { Hanford formation soil are presented. }\end{array}$ & Engleman et al. 1995, pp. 3-5. \\
\hline $\begin{array}{l}\text { Bulk density and moisture content data with depth presented for } \\
\text { boreholes in the 200 East Area }\end{array}$ & Fayer et al. 1999, Tables B.3-B.9 \\
\hline $\begin{array}{l}\text { Bulk density and moisture content data with depth for the Hanford } \\
\text { Site's 100 B/C, 100 K, 100 D/DR, 100 H, and 100 F Areas }\end{array}$ & $\begin{array}{l}\text { Peterson et al. 1996, Tables 3-8, 4-9, 6-9, } \\
7-9, \text { and 8-8 }\end{array}$ \\
\hline Moisture content data for inside U.S. Ecology trench & Dunkelman 2000, Table 8, p. 34 \\
\hline $\begin{array}{l}\text { Source bulk density and moisture content data for U.S. Ecology } \\
\text { performance assessment }\end{array}$ & Rood 2000, pp. 4-5 \\
\hline $\begin{array}{l}\text { Moisture content data with depth are provided for soil from the } \\
\text { 300 Area }\end{array}$ & $\begin{array}{l}\text { Schalla et al. 1988, Appendix B, p. B.2, } \\
\text { Table B.2 }\end{array}$ \\
\hline $\begin{array}{l}\text { Bulk density and moisture content values used in a comparative } \\
\text { groundwater pathway analysis of low-level waste burial grounds }\end{array}$ & $\begin{array}{l}\text { DOE 2002, Appendix L, Table L.2, } \\
\text { p. L.19. }\end{array}$ \\
\hline \hline
\end{tabular}

\subsubsection{Aqueous Solubility Data for Soil-Debris Model}

Table 4.6 summarizes sources of solubility data that can be used in a constant concentration release of a contaminant using the soil-debris model.

Table 4.6. Sources of Solubility Data for Soil-Debris Model

\begin{tabular}{||l|l||}
\hline \multicolumn{1}{|c||}{ Information Source Summary } & \multicolumn{1}{c||}{ Reference } \\
\hline \hline $\begin{array}{l}\text { Solubility data for the soil-debris model as applied to the System } \\
\text { Assessment Capability initial run (SAC Rev. 0) are summarized }\end{array}$ & Riley and Lo Presti 2001b \\
\hline $\begin{array}{l}\text { Aqueous solubility data for selected radionuclides used in 200 Area } \\
\text { plateau composite analysis }\end{array}$ & $\begin{array}{l}\text { Kincaid et al. 1998, Appendix D, } \\
\text { Table D.2 }\end{array}$ \\
\hline $\begin{array}{l}\text { Aqueous solubility data for selected metals in cement leachates and } \\
\text { Hanford groundwater }\end{array}$ & Wood et al. 1995a, Appendix E \\
\hline $\begin{array}{l}\text { Calculated aqueous solubilities for selected radionuclides and metals } \\
\text { for Hanford's 200 West and East Areas as applied to the Waste } \\
\text { Isolation Pilot Plant No-Action Alternative }\end{array}$ & Buck et al. 1996, Appendix B, Table B.2 \\
\hline $\begin{array}{l}\text { Aqueous solubilities for organic, inorganic and radionuclide } \\
\text { constituents used in ERDF remedial investigation feasibility studies }\end{array}$ & DOE 1994, Tables 4.6, 4.7, and 4.8 \\
\hline $\begin{array}{l}\text { Aqueous solubilities for organic, inorganic and radionuclide } \\
\text { constituents used in ERDF screening performance assessment/risk } \\
\text { assessment }\end{array}$ & Roeck 1993, p. 3-9, Table 3-4 \\
\hline $\begin{array}{l}\text { Solubility of uranium in soil-dominated and Portland cement- } \\
\text { dominated environments for ERDF performance assessment }\end{array}$ & Wood et al. 1995b, p. 3-15 \\
\hline Discussion of actinide solubilities in cement pore water & Criscenti et al. 1996, p. 1.3 \\
\hline
\end{tabular}


Table 4.6. (contd)

\begin{tabular}{||l|l||}
\hline \multicolumn{1}{|c|}{ Information Source Summary } & \multicolumn{1}{|c||}{ Reference } \\
\hline \hline $\begin{array}{l}\text { Radionuclide solubility data for Nuclear Regulatory Commission } \\
\text { performance assessment test case }\end{array}$ & Krupka and Serne 1998, pp. 4.1-4.31 \\
\hline $\begin{array}{l}\text { Radionuclide solubility data for TRU waste no disposal action } \\
\text { scenario }\end{array}$ & $\begin{array}{l}\text { DOE 1987, Volume 3, Appendix P, } \\
\text { Table P.26 }\end{array}$ \\
\hline Solubility of PCB in water for reactor compartment assessment & DOE 1996c, p. 4-31 \\
\hline $\begin{array}{l}\text { Aqueous solubility of lead for assessment of reactor compartment } \\
\text { source-term }\end{array}$ & Rhoads et al. 1992, Table 3.7, p. 3.19 \\
\hline $\begin{array}{l}\text { Solubility values used in groundwater pathway analysis of } \\
\text { U.S. Ecology low-level waste disposal site }\end{array}$ & Rood 2000, p.7 \\
\hline $\begin{array}{l}\text { Solubility values for solubility-controlled release from contaminated } \\
\text { soils }\end{array}$ & Serne and Wood 1990, p. 2.25 \\
\hline $\begin{array}{l}\text { Solubility values used in a comparative groundwater pathway analysis } \\
\text { of low-level waste burial grounds }\end{array}$ & $\begin{array}{l}\text { DOE 2002, Appendix L, Table L.2, } \\
\text { p. L.19. }\end{array}$ \\
\hline $\begin{array}{l}\text { ERDF = Environmental Restoration Disposal Facility. } \\
\text { PCB = Polychlorinated biphenyl. } \\
\text { TRU }=\text { Transuranic (waste). }\end{array}$ & \\
\hline \hline
\end{tabular}

Values of aqueous solubility are derived from experimental measurements or estimated based on geochemical calculations (e.g., using the MINTEQA2 computer code). In cases where the solubility of a constituent is unknown, the aqueous solubility can be fixed at an arbitrarily high default value forcing the soil-debris model to operate in the desorption-controlled mode. In many cases, constituents without solubility values are not solubility-limited in aqueous solution. The soil-debris model may require solubility values in units of $\mathrm{Ci} / \mathrm{cm}^{3}$. In this case, solubility values measured in $\mathrm{mg} / \mathrm{L}$ are converted to $\mathrm{Ci} / \mathrm{cm}^{3}$ by multiplying by the specific activity of each radionuclide (along with appropriate unit conversion factors). The specific activity was calculated from the decay half-life and the atomic mass according to the formula (DOHEW 1970):

$$
\mathrm{A}=3.578 \times 10^{5} / \mathrm{t}_{1 / 2} \mathrm{M}
$$

where $\quad \mathrm{A}=$ the specific activity of the contaminant $(\mathrm{Ci} / \mathrm{g})$

$\mathrm{T}_{1 / 2}=$ the decay half-life (yrs) of the contaminant

$\mathrm{M}=$ the atomic mass of the contaminant $(\mathrm{g} / \mathrm{mol})$

\subsubsection{Other Data for the Soil Debris-Model}

The soil-debris model requires cross sectional area and height (depth) information for the waste source zone. This data can vary significantly depending on the dimensional scale to which the modeling is being performed. For example, the model may be applied to a specific waste site footprint (e.g., a lowlevel waste burial ground) in which case the data would consist of the dimensions of the waste site). In another case, low-level waste burial grounds within a given Hanford area (e.g., 200 West Area) may be aggregated and a cross-sectional area footprint assigned that is the sum of the cross-sectional areas for all of the low-level waste burial grounds in the 200 West Area. This type of scaling is most recently 
observed in the application of the soil-debris model to the System Assessment Capability initial assessment (Riley and Lo Presti 2001b). Feature data (i.e., dimensions) for specific source zones and model source zones for the soil-debris model and the other release models (Sections 3.2, 3.3, and 3.4) can be found in Table 4.7.

Table 4.7. Sources of Waste Zone or Waste Form Feature Data for Release Models

\begin{tabular}{|c|c|}
\hline Information Source Summary & Reference \\
\hline $\begin{array}{l}\text { Cross-sectional areas (and/or length/width) and height (depth) data for } \\
\text { the soil-debris model as applied to the System Assessment Capability } \\
\text { initial run (SAC Rev. 0) is summarized }\end{array}$ & Riley and Lo Presti 2001b \\
\hline $\begin{array}{l}\text { Cross-sectional areas (and/or length/width) and height (depth) data for } \\
\text { Hanford Site waste source zones }\end{array}$ & WIDS database \\
\hline $\begin{array}{l}\text { Cross-sectional areas (and/or length/width) and height (depth) data for } \\
\text { Hanford Site waste source zones }\end{array}$ & $\begin{array}{l}\text { Stenner et al. 1988, Volumes } 2 \text { and } 3 \\
\text { Hanford Inactive Site Surveillance (HIIS) } \\
\text { database }\end{array}$ \\
\hline $\begin{array}{l}\text { Waste site volumes (as a substitute for cross-sectional area X height) } \\
\text { for application of release models to Central Plateau composite analysis }\end{array}$ & Kincaid et al. 1998, Table 4.3 \\
\hline $\begin{array}{l}\text { Model waste configurations (height, cross-sectional areas, volumes) for } \\
\text { buried TRU waste at Hanford as applied to Waste Isolation Pilot Plant } \\
\text { No-Action Alternative }\end{array}$ & Buck et al. 1996, pp. 6.1-6.4 \\
\hline ERDF and trench dimensions & $\begin{array}{l}\text { DOE 1994, p. 4-2, Figure 4-1; WHC 1993a, } \\
\text { p. 3-3, Figure 3-3 }\end{array}$ \\
\hline Geometry data for TRU sites at Hanford & $\begin{array}{l}\text { DOE 1987, Volume 3, Appendix P, } \\
\text { pp. p.20-p.21; Table P.26, p.40 }\end{array}$ \\
\hline $\begin{array}{l}\text { Treatment of disposal facility features in low-level waste performance } \\
\text { assessment analysis (200 West Area) }\end{array}$ & $\begin{array}{l}\text { Wood et al. 1995a, pp. 2-32-2-36, Fig- } \\
\text { ure 2-15; p. 3-27 }\end{array}$ \\
\hline $\begin{array}{l}\text { Treatment of disposal facility features in low-level waste performance } \\
\text { assessment analysis (200 East Area) }\end{array}$ & $\begin{array}{l}\text { Wood et al. 1996, pp. 2-21-2-22, Fig- } \\
\text { ures 2-12, 2-13, 2-14, 2-15, 2-16, and 2-17 }\end{array}$ \\
\hline $\begin{array}{l}\text { Conceptual model of ERDF four cell facility for performance } \\
\text { assessment }\end{array}$ & $\begin{array}{l}\text { Wood et al. 1995b, p.2-19, Figure 2-13 } \\
\text { (p. 2-35) }\end{array}$ \\
\hline Dimensions of waste packages associated with solid waste disposal & $\begin{array}{l}\text { Greenhalgh 1995, p. 2-1; Table 2-1, } \\
\text { pp. 2-6-2-7; Figures 2-4-2-6, 2-8, } \\
\text { pp. 2-8-2-13 }\end{array}$ \\
\hline $\begin{array}{l}\text { High-level waste tank cross-sectional areas for the salt cake model as } \\
\text { applied to the System Assessment Capability initial run (SAC Rev. 0) }\end{array}$ & Last et al. 2001 \\
\hline $\begin{array}{l}\text { High-level waste tank cross-sectional areas (calculated from diameter } \\
\text { data) }\end{array}$ & WHC 1994a, Appendix D, p. D-3 \\
\hline $\begin{array}{l}\text { Reactor compartment (decommissioned nuclear submarine and cruiser } \\
\text { compartments) footprint information }\end{array}$ & DOE 1996c, Figure 2.1, p. 2-7 \\
\hline $\begin{array}{l}\text { Reactor compartment (decommissioned nuclear submarine and cruiser } \\
\text { compartments) burial ground configuration information }\end{array}$ & $\begin{array}{l}\text { DOE 1996c, Figures } 2.10 \text { and 2.12, pp. 2-19 } \\
\text { and 2-21 }\end{array}$ \\
\hline Model footprint for release of lead from reactor compartments & Rhoads et al. 1992, p 4.1-4.2 \\
\hline $221 \mathrm{U}$ facility footprint (also model footprint for B-Plant and T-Plant) & DOE 1998, Figures $1-3$ and $1-5$ \\
\hline Grout disposal vault features & Kincaid et al. $1995 \mathrm{a}$, p. $2.70-2.78$ \\
\hline High integrity container designs and features & Josephson 1996, p. 2-3 \\
\hline
\end{tabular}


Table 4.7. (contd)

\begin{tabular}{|c|c|}
\hline Information Source Summary & Reference \\
\hline Low-level waste burial ground waste packages & $\begin{array}{l}\text { Wood et al. 1995a, p. 2-30; Wood et al. } \\
\text { 1996, p. 2-20 }\end{array}$ \\
\hline $\begin{array}{l}\text { Cross sectional areas for fuel storage basins and ground disposal sites } \\
\text { associated with surplus production reactors }\end{array}$ & DOE 1989, Appendix C, p. C.4 \\
\hline Design of disposal of surplus production reactors & DOE 1989, Appendix H, p. C.4 \\
\hline $\begin{array}{l}\text { Surplus production reactor design data (graphite stack, process tubes, } \\
\text { thermal shield, biological shield) }\end{array}$ & Miller and Steffes 1987, p. 11, Table 2 \\
\hline Typical reactor block dimensions & Romano and Miller 1995 \\
\hline $\begin{array}{l}\text { Dimensions of decommissioned nuclear reactor compartment waste } \\
\text { packages }\end{array}$ & DOE 1996c, Figure 2.1, p. 2-7 \\
\hline Dimensions of trench 94 in 218-E-12B low-level waste burial ground & $\begin{array}{l}\text { DOE } 1996 \mathrm{c} \text {, Figures } 2.10 \text { and } 2.12, \text { p. } 2-19 \\
\text { and 2-21 }\end{array}$ \\
\hline $\begin{array}{l}\text { Dimensions used to model release of constituents from trench } 94 \text { in } \\
218 \text {-E-12B burial ground }\end{array}$ & $\begin{array}{l}\text { DOE } 1996 \mathrm{c} \text {, Figure } 4.2 \text {, p. } 4-18 \text { and Figure } \\
4.3 \text {, p. } 4-21\end{array}$ \\
\hline Number and dimensions of U.S. Ecology low-level waste trenches & $\begin{array}{l}\text { WDOE 2000, Section 1.1, p.1, Executive } \\
\text { Summary, Section 3.0, p. } 3\end{array}$ \\
\hline Size of Trojan reactor vessel in U.S. Ecology trench & $\begin{array}{l}\text { WDOE 2000, Section 2.3.2, p. 52, Executive } \\
\text { Summary }\end{array}$ \\
\hline $\begin{array}{l}\text { Waste package arrays for decommissioned nuclear reactor } \\
\text { compartment waste packages }\end{array}$ & $\begin{array}{l}\text { Rhoads et al. } 1994 \text {, p. } 4.1 \text {; Rhoads et al. } \\
\text { 1992, p. } 4.16\end{array}$ \\
\hline $\begin{array}{l}\text { Surface areas associated with decommissioned nuclear reactor } \\
\text { compartment arrays }\end{array}$ & Rhoads et al. 1994, p. 4.2 \\
\hline $\begin{array}{l}\text { Remote handled trench and concrete vault conceptual designs for } \\
\text { ILAW waste }\end{array}$ & $\begin{array}{l}\text { Mann et al. 2000, pp. 8-12, Figures 2.3, 2.4, } \\
2.5,2.6 \text {, and } 2.7\end{array}$ \\
\hline ILAW waste package geometry & Mann et al. 2000, pp. $40-41$ \\
\hline Material zones for remote handled trench and concrete vault & Mann et al. 2000, pp. 53-55 \\
\hline Estimate number of waste packages for ILAW waste & Mann et al. 2000, p. 20 \\
\hline Area-to-volume ratio for 55-gallon drum & Wood et al. 1996, p. 3-18 \\
\hline ILAW disposal designs & Mann et al. 1998 , pp. 2-51-2-57, p. 2-61 \\
\hline ILAW vault dimensions & Mann et al. 1998, pp 3-43-3-44 \\
\hline Updated ILAW trench dimensions & Burbank 2001, pp. 10-11 \\
\hline ILAW vault and trench dimensions for simulations & Bacon and McGrail 2001, p 17 \\
\hline $\begin{array}{l}\text { Waste thickness values used in a comparative groundwater pathway } \\
\text { analysis of low-level waste burial grounds }\end{array}$ & DOE 2002, Appendix L, Table L.2, p. L.19. \\
\hline Waste depth values for use of soil-debris model & DOE 2002, Appendix G, Table G.3, p. G.15. \\
\hline ERDF $=$ Environmental Restoration Disposal Facility. & \\
\hline$=$ Immobilized low-activity waste & \\
\hline$=$ Hanford Inactive Site Surveillance. & \\
\hline$=$ Transuranic (waste) & \\
\hline$=$ Waste Information Data System. & \\
\hline
\end{tabular}


The soil-debris model has a recharge rate term. In general, recharge rates applied are those used in vadose zone modeling and vary based on site conditions (e.g., soil type, presence or absence of a cover). Recharge rate data sources are summarized in Table 4.8.

Some previous assessments have modified the soil-debris model to take into account other factors that effect contaminant release from a source zone. Such factors include soil erosion due to wind and water

Table 4.8. Sources of Recharge Rate Data for Release Models

\begin{tabular}{|c|c|}
\hline Information Source Summary & Reference \\
\hline $\begin{array}{l}\text { Estimated recharge rates as applied to the System Assessment } \\
\text { Capability initial run (SAC Rev. 0) are summarized }\end{array}$ & Last et al. 2001 \\
\hline Estimated recharge rates for ILAW performance assessment & Fayer et al. 1999, pp. iii-iv; p 2.2 \\
\hline Recharge rates for low-level waste performance assessments & Rockhold et al. 1995 \\
\hline Variations in recharge at the Hanford Site & Gee at al. 1992 \\
\hline $\begin{array}{l}\text { Recharge rates for low-level waste performance assessment in } \\
200 \text { West Area }\end{array}$ & Wood et al. 1995a, pp. 3-16-3-17 \\
\hline $\begin{array}{l}\text { Recharge rates for low-level waste performance assessment in } \\
200 \text { East Area }\end{array}$ & Wood et al. 1996, pp. 3-19-3-20 \\
\hline Infiltration rates for ERDF RIFS assessments & DOE 1994, pp. 4-2-4-3; Roeck 1993, p. 3-1 \\
\hline Infiltration rates for HDWEIS & DOE 1987, Appendix Q, pp. Q.1-Q.2 \\
\hline Infiltration rates for TWRS EIS remediation scenarios & DOE 1996b, Appendix F, pp. F-39-F-63 \\
\hline $\begin{array}{l}\text { Estimated recharge rates as applied to the System Assessment } \\
\text { Capability initial run (SAC Rev. 0) }\end{array}$ & DOE 2002, Appendix I, Table I.2 \\
\hline Recharge for Hanford grout performance assessment & Kincaid et al. $1995 \mathrm{a}$, p. 4.56 \\
\hline Recharge rate for RESRAD modeling of Hanford Site 116-C-1 & BHI 1999, pp. 35 and 37 \\
\hline $\begin{array}{l}\text { Recharge rates for modeling release of contaminants from } \\
\text { decommissioned nuclear reactor compartments }\end{array}$ & $\begin{array}{l}\text { Rhoads et al. 1994, p. ix; p. 4.3; } \\
\text { p. 4.34-4.35 }\end{array}$ \\
\hline Recharge rate estimates for vitrified waste & Kline 1996, p. 4 \\
\hline Recharge rate estimates for ILAW waste & Mann et al. 2000, p. 45 \\
\hline Recharge rates for single-shell tanks & Serne and Wood 1990, p. 2.13 \\
\hline Recharge rates for ERDF performance assessment & Wood et al. 1995b, p. 3-15 \\
\hline Natural recharge rates and infiltration rates for ILAW assessment & $\begin{array}{l}\text { Mann et al. 1998, pp. 2-37-2-38; } \\
\text { pp. 3-48 }\end{array}$ \\
\hline Recharge rate for ILAW simulations & Bacon and McGrail 2001, p. iii \\
\hline $\begin{array}{l}\text { Recharge data for different cover types for U.S. Ecology site } \\
\text { assessment }\end{array}$ & $\begin{array}{l}\text { Dunkelman 2000, Section 3.0, p. 6, Table 5, } \\
\text { p. 27, Table 8, p. } 34\end{array}$ \\
\hline Recharge data for S-SX Field Investigation & Khaleel et al. 2000, pp. 5-6 \\
\hline Infiltration rate values for use of soil-debris model & DOE 2002, Appendix G, Table G.3, p. G.15 \\
\hline $\begin{array}{l}\text { Recharge rates for conduct of initial assessment of closure for C Tank } \\
\text { Farm }\end{array}$ & Khaleel et al. 2002, pp. 10-11 \\
\hline \multicolumn{2}{|c|}{\begin{tabular}{|ll} 
ERDF & $=$ Environmental Restoration Disposal Facility. \\
HDWEIS & $=$ Hanford defense waste environmental impact statement. \\
ILAW & $=$ Immobilized low-activity waste. \\
TWRS EIS & $=$ Tank waste remediation system environmental impact statement.
\end{tabular}} \\
\hline
\end{tabular}


(Buck et al. 1996) and hydrodynamic dispersion (Wood et al. 1995a). Table 4.9 summarizes sources of such data and how they are incorporated into the conventional soil-debris model formulation.

Table 4.9. Other Sources of Data for Soil-Debris Model

\begin{tabular}{||l|l||}
\hline \multicolumn{1}{|c|}{ Information Source Summary } & \multicolumn{1}{c|}{ Reference } \\
\hline \hline Wind and water erosion rates for Hanford Site soil & Buck et al. 1996, p. 7.2 \\
\hline Dispersion coefficient for advective dominated release model & Wood et al 1995a, pp. 3-12-3-13 \\
\hline
\end{tabular}

\subsection{Solubility $\left(\mathrm{C}_{\text {sol }}\right) /$ Constant Concentration Model}

The solubility/constant concentration $\left(\mathrm{C}_{\mathrm{sol}}\right)$ model is the independently operated analytical solution component of the soil-debris model. As such, it is applied to the same types of solid wastes that is applied to the soil-debris model. The difference is that the process represented by the $\mathrm{C}_{\text {sol }}$ model is that of constant concentration release. The concentration at which a contaminant is released from a waste often is at its solubility limit in some aqueous medium (e.g., groundwater or grout leachate) in the case of the soil-debris model but is not a requirement in the application of this model. This is different from application of the same analytical solution within the soil-debris model where the model determines which process (solubility vs. sorption controlled) is the appropriate for application at any time within a simulation. In the soil-debris model, release is always at what is considered to be the solubility limit of the contaminant in the aqueous media of interest.

The rate of loss of contaminant for a given contaminant by the solubility/constant concentration model is given by:

$$
d M / d t=-Q A C_{w}
$$
Kincaid et al. 1998)

where $\boldsymbol{C}_{\boldsymbol{w}}=\boldsymbol{C}_{\text {sol }}$ in Equation D.35 when the release process is solubility-controlled.

Constant concentration levels at below the solubility limit for any analyte of interest can also be applied in the model. Tables of data listed for the soil-debris model (Tables 4.6, 4.7, and 4.8) are applicable to this model.

\subsection{Saltcake Model}

The saltcake model consists of a very simple mathematical formulation containing a recharge rate term, a term for waste solid solubility, and a term for the cross-sectional area of the waste source (i.e., single and double-shell tank footprint).

The contaminant release mechanism of the saltcake model is the dissolution of the structural matrix. As the matrix dissolves, all the contaminants are assumed to leach congruently at the same rate. When applied to the Hanford high-level waste tanks, the term "saltcake" applies to the saltcake, sludge, and hard 
heel residual in the tanks, which compose the "structural matrix." The release rate for a given contaminant is given by:

$$
D M / d t=M_{o} A Q_{w} C_{w o} / M_{w o}
$$

(after Equation D.48, p. D.14,

Kincaid et al. 1998)

where $\quad \mathrm{M}_{\mathrm{wo}}=$ the original mass of salt cake $(\mathrm{kg}) . \mathrm{M}_{\mathrm{wo}}$ may also be derived by the product of tank waste volume and waste density.

$\mathrm{M}_{\mathrm{o}}=$ the original quantity of contaminant in $\mathrm{Ci}$ or $\mathrm{kg}$ embedded in the saltcake

$\mathrm{M}=\mathrm{M}(\mathrm{t})$ is the current quantity of the contaminant contained in the saltcake (Ci or $\mathrm{kg})$ at time $\mathrm{t}$

$\mathrm{A}=$ the surface area of saltcake exposed to the release mechanism $\left(\mathrm{cm}^{2}\right)$

$\mathrm{C}_{\mathrm{wo}}=$ the aqueous solubility of the saltcake simulated as a nitrate salt $\left(\mathrm{g} / \mathrm{cm}^{3}\right)$

$\mathrm{Q}_{\mathrm{w}}=$ the site recharge rate in $\mathrm{cm} / \mathrm{yr}$, also termed "infiltration rate"

$\mathrm{dM} / \mathrm{dt}=$ the rate of loss of contaminant from the saltcake waste form per unit time $\mathrm{t}$ (the rate at which the contaminant enters the environment)

Recharge rates for the saltcake model are handled in a similar fashion to the soil-debris model. Sources of data on recharge and cross-sectional area for this model can also be found in Tables 4.7 and 4.8 , respectively. Cross-sectional footprints for the saltcake model can consist, for example, of an individual tank, a tank farm, or a cluster of tank farms in a specific Hanford area.

In many cases, the dissolving solid is considered to be a nitrate salt and contaminants imbedded in the solid dissolve congruently with the nitrate. Nitrate concentrations measured in tank high-level waste pore fluids and supernate and used in Hanford assessments have varied. The concentration most commonly used today is $360 \mathrm{~g} / \mathrm{L}$. A density value is required to convert tank waste volumes to equivalent masses (Table 4.10). An alternative to congruent release depicted by the saltcake model is solubility-controlled release where radionuclides are carried away from the source at their maximum solution concentration (Serne and Wood 1990, Appendix A, Table A.1).

Table 4.10. Sources of Data for Saltcake Model

\begin{tabular}{||l|l||}
\hline \multicolumn{1}{|c||}{ Information Source Summary } & \multicolumn{1}{c||}{ Reference } \\
\hline \hline Bottom diameters of single shell- and double shell tanks & WHC 1994a, p. D-3, WHC 1994a \\
\hline \hline $\begin{array}{l}\text { Nitrate salt solubility as applied to the System Assessment } \\
\text { Capability initial run (SAC Rev. 0) is summarized }\end{array}$ & Riley and Lo Presti 2001b \\
\hline $\begin{array}{l}\text { Nitrate salt solubility concentrations found in high-level waste tank } \\
\text { drainable liquors }\end{array}$ & Serne and Wood 1990, pp. 2.27 and 2.33 \\
\hline $\begin{array}{l}\text { Nitrate salt solubility concentration used in TWRS EIS release } \\
\text { model simulations }\end{array}$ & DOE 1996b, Appendix F, pp. F-39-F-63 \\
\hline Tank solid waste density & Chen et al. 1998, Table 3.6, p. 3.18 \\
\hline TWRS EIS = Total waste remediation system environmental impact statement. \\
\hline
\end{tabular}




\subsection{Cement Model}

The cement model is generally applied to cementitious waste forms. A knowledge of the total external surface area and the volume of the waste form are required. The ratio of area to volume is assumed to be constant, that is, the waste form is assumed not to degrade in terms of shape over the duration of the contaminant release process.

The contaminant release mechanism of the cement model is diffusion in the pore water of the solidified waste material to the outer surface of the waste form. The rate of loss of contaminant for a given contaminant is given by:

$$
d M / d t=M_{o}(A / V)(D / \pi t)^{1 / 2}
$$

where $\quad \mathrm{M}_{0}=$ the original quantity of the contaminant contained in the cement (Ci or $\left.\mathrm{kg}\right)$. This can be seen as a function of concentration $\left(\mathrm{kg} / \mathrm{cm}^{3}\right.$ or $\left.\mathrm{Ci} / \mathrm{cm}^{3}\right)$ and volume $\left(\mathrm{cm}^{3}\right)$

$\mathrm{M}=$ current quantity of the contaminant contained in the cement $(\mathrm{Ci}$ or $\mathrm{kg}$ )

$\mathrm{A}=$ the surface area of the cement structure $\left(\mathrm{cm}^{2}\right)$

$\mathrm{V}=$ the volume of the cement structure $\left(\mathrm{cm}^{3}\right)$

$\mathrm{D}=$ the diffusion coefficient of the contaminant $\left(\mathrm{cm}^{2} / \mathrm{yr}\right)$

$\mathrm{t}=$ the elapsed time (years) from the beginning of release from containment

$\mathrm{dM} / \mathrm{dt}=$ the rate of loss of contaminant from the cement waste form

Data for parameters for the cement model can be found in Table 4.7. The most important term in the model is the effective diffusion coefficient, which governs the migration of contaminants from inside the waste form to the waste form surface where they are removed by infiltrating water. It is assumed that cementitious waste forms have sufficient permeability to allow the diffusion process to occur in the waste form pore water. Most effective diffusion coefficients are derived from experiments performed under saturated moisture conditions. Application of such coefficients in release models would result in faster contaminant releases to the vadose zone than would be anticipated at the Hanford Site. Most recently, diffusion coefficients for selected radionuclides have been determined for unsaturated conditions more representative of the Hanford Site (Mattigod et al. 2001).

Competing with diffusion of contaminants out of the waste form is dissolution or corrosion of the cementitious material with subsequent release of contaminants to the surrounding environment. Geochemical modeling of the dissolution of cementitious materials suggests slow degradation of cement materials in a radioactive waste disposal system environment. Pore fluid composition of $\mathrm{pH}$ above 10.5 is predicted for several hundred thousand years during dissolution of the calcium silicate hydrogel (C-S-H) and Portlandite phases of cementitious materials. These phases constitute up to $75 \mathrm{wt} \%$ of the cement. A study of natural analog systems indicates the stability of cementitious materials on time frames of thousands of years (Krupka and Serne 1998). Sources of diffusion coefficient and dissolution rate data can be found in Table 4.11. 
Table 4.11. Sources of Data for Cement Model

\begin{tabular}{|c|c|}
\hline Information Source Summary & Reference \\
\hline $\begin{array}{l}\text { Diffusion data for the cement model as applied to the System } \\
\text { Assessment Capability initial run (SAC Rev. 0) are summarized }\end{array}$ & Riley and Lo Presti 2001b \\
\hline Diffusion coefficients for grouted low-level waste forms & $\begin{array}{l}\text { Serne et al. } 1992, \text { Table } 6, \text { p. } 277 ; \text { Table } 8, \\
\text { p. } 279 ; \text { Table } 9, \text { p. } 280 ; \text { Table } 11, \text { p. } 281 ; \\
\text { Tables } 12 \text { and } 13, \text { p. } 282\end{array}$ \\
\hline $\begin{array}{l}\text { Diffusion coefficients for encasement cement concrete and soil fill } \\
\text { materials }\end{array}$ & $\begin{array}{l}\text { Mattigod et al. 2001, Tables } 4.8 \text { and } 4.9, \\
\text { p. } 4-23\end{array}$ \\
\hline $\begin{array}{l}\text { Diffusion coefficients as applied to the Central Plateau composite } \\
\text { analysis }\end{array}$ & Kincaid et al. 1998, Appendix D, Table D.2 \\
\hline Diffusion coefficients in support of WIPP no-action alternative 2 & Buck et al. 1996, Appendix B, Table B.4. \\
\hline Effective diffusion coefficients for ERDF assessments & Roeck 1993, p. 3-6; Table 3-4, p. 3T-4 \\
\hline $\begin{array}{l}\text { Diffusion coefficients in support of grout low-level waste } \\
\text { performance assessment }\end{array}$ & Kincaid et al. 1995a, Table 3.3, p. 3.37 \\
\hline $\begin{array}{l}\text { Diffusion coefficients in support of } 200 \text { West Area low-level waste } \\
\text { performance assessment }\end{array}$ & Wood et al. 1995a, p. 3-16 \\
\hline $\begin{array}{l}\text { Diffusion coefficients in support of } 200 \text { East Area low-level waste } \\
\text { performance assessment }\end{array}$ & Wood et al. 1996, p. 4-12 \\
\hline Diffusion coefficients for grout performance assessment & $\begin{array}{l}\text { Serne and Wood 1990, p. 2.19, 2.22-2.23; } \\
\text { Table 18, pp. 2.52-2.53; Appendix A, } \\
\text { Table A.2 }\end{array}$ \\
\hline Effective diffusion coefficients for grout waste forms & $\begin{array}{l}\text { Kincaid et al. 1995b, Appendix P, } \\
\text { p. P.20-P.24 }\end{array}$ \\
\hline Dissolution rates for fixated waste (cementitious) & Roeck 1993, p. 3-6 \\
\hline Time frame for dissolution of cement & Krupka and Serne 1998, p. 2.2 \\
\hline Natural analogs of cement and concrete materials & $\begin{array}{l}\text { Krupka and Serne 1998, pp. } 2.4-2.5 ; \\
\text { Appendix C }\end{array}$ \\
\hline $\begin{array}{l}\text { Effective diffusion coefficient values used in a comparative } \\
\text { groundwater pathway analysis of low-level waste burial grounds }\end{array}$ & DOE 2002, Appendix L, Table L.2, p. L.19 \\
\hline $\begin{array}{l}\text { Diffusion coefficient for diffusion-dominated release of high-level } \\
\text { waste tank residuals. }\end{array}$ & Kahleel et al. 2002, p. 30 \\
\hline $\begin{array}{l}\text { ERDF }=\text { Environmental Restoration Disposal Facility. } \\
\text { WIPP }=\text { Waste Isolation Pilot Project. }\end{array}$ & \\
\hline
\end{tabular}

The cement model can also be used to simulate the release of contaminants stabilized in cementitious encasements (e.g., high-integrity containers, or entombed underground portions of decommissioned buildings). In this case, the release of contaminants is additionally controlled by the need for the contaminants to pass through the encasement material. Diffusion, dissolution, and corrosion properties of the encasement materials control such migration. Lastly, cementitious materials (i.e., both waste forms and encasements) can be chemically converted in the environment to waste forms of greater stability and more restrictive migration properties (i.e., lower diffusivity). The conversion of cement to carbonate is an example (Mattigod et al. 2001). 


\subsection{Reactor Block Model}

The reactor block model is used to simulate release of contaminants from decommissioned surplus production reactors on the Hanford Site. The model formulation is simple, containing only a mass and fractional release term. With the exception of carbon-14, release modeling of selected other contaminants of surplus production has been based on fractional release rates. These release rates have been calculated from experimental leach rates (White et al. 1984) and Hanford reactor configurations.

The contaminant release mechanism of the reactor-block model is leaching contaminants from the graphite blocks of the production reactors. The rate of loss of contaminant for a given contaminant is given by:

$$
d M / d t=-M_{o} F_{r r r}
$$
Kincaid et al. 1998)

where $\mathrm{M}_{\mathrm{o}}=$ the initial quantity in $\mathrm{Ci}$ or $\mathrm{kg}$ of contaminant in the graphite core

$\mathrm{F}_{\mathrm{rrr}}=$ the fractional release rate in $\mathrm{yr}^{-1} . \mathrm{F}_{\mathrm{rrr}}$ is analyte specific and its value ranges from 0 to 1

This model, described originally in the surplus production reactor EIS (DOE 1989), generates a family of curves such that the smaller the value of $F_{\text {rrr }}$, the more elapsed time is required until a specific contaminant inventory is completely depleted from the graphite block. $\mathrm{M}_{\mathrm{o}}$ serves as a multiplier or scaler.

The surplus production EIS (DOE 1989) used a temperature dependent fractional release for calculating the release of carbon 14 from the reactor block. The fractional rate was defined as

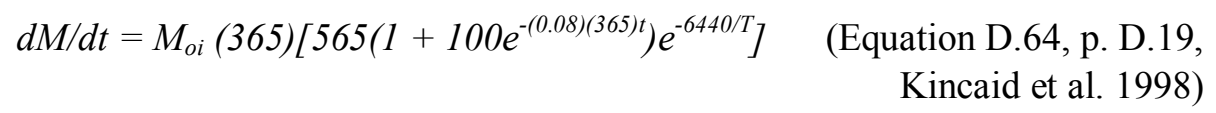

where $\mathrm{M}_{\mathrm{oi}}=$ the initial quantity in Ci or $\mathrm{kg}$ of contaminant in the graphite core

$\mathrm{T}=$ the absolute temperature of the reactor block $(\mathrm{K})$

Sources of data for the reactor block model can be found in Table 4.12.

Table 4.12. Sources of Data for Reactor Block Model

\begin{tabular}{||l|l||}
\hline \multicolumn{1}{|c|}{ Information Source Summary } & \multicolumn{1}{|c||}{ Reference } \\
\hline \hline $\begin{array}{l}\text { Fractional release data for reactor block model as applied to the System } \\
\text { Assessment Capability initial run (SAC Rev. 0) are summarized }\end{array}$ & Riley and Lo Presti 2001b \\
\hline Release rates from surplus reactor graphite cores & DOE 1989, Appendix C, Table C.1 \\
\hline Corrosion rates of shielding and metal components of surplus reactors & DOE 1989, Appendix C, p. C.4 \\
\hline Release rates of carbon-14 from surplus production reactors & DOE 1989, Appendix D, pp. D.1-D.3 \\
\hline $\begin{array}{l}\text { Other sources of radionuclides and their releases from surplus production } \\
\text { sources }\end{array}$ & DOE 1989, Appendix D., p. D.6 \\
\hline Solubility of lead in Hanford groundwater & DOE 1989, p. 5.21 \\
\hline $\begin{array}{l}\text { Leach rates used to derive fractional release rates for surplus production } \\
\text { reactors }\end{array}$ & White et al. 1984, pp. 42-61. \\
\hline Release rates of carbon-14 from surplus production reactors & $\begin{array}{l}\text { Kincaid et al. 1998, Appendix D, } \\
\text { pp. D.18-D.19 }\end{array}$ \\
\hline
\end{tabular}




\subsection{Glass Model}

The glass model is used to simulate contaminant release from vitrified waste. Three analytical solutions are described. In the first analytical solution, it is like the cement model, requiring data on the total surface area and volume of the waste form. Unlike cement waste forms, however, vitrified waste is considered impermeable and therefore diffusion of contaminants out of the waste form to the waste form surface is not considered a relevant mechanism. Instead, contaminant release is governed by slow dissolution of the glass waste form (Kincaid et al. 1998). In the second analytical solution, contaminant release is represented as a function of a fractional release rate of a specific contaminant from the waste form (Kincaid et al. 1998; Mann et al. 1998). In the third analytical solution, a mechanistic approach is taken where dissolution of the glass, influenced by local chemical conditions, is assumed to control the release rate of radionuclide contaminants. A general rate equation was formulated that describes the dissolution of glass as a function of key parameters (e.g., $\mathrm{pH}$ ). This rate equation was subsequently reflected within an equation that expressed the normalized flux of radionuclides to the vadose zone for glass waste packages (Bacon and McGrail 2001). The third analytical solution is considerably more advanced and representative of contaminant release from glass than the other two solutions.

For the first analytical solution, the rate of release of contaminant is given by:

$$
d M / d t=-M_{o i}(A / V) r
$$

(Equation D.52, p. D.15, Kincaid et al. 1998)

where $\quad \mathrm{M}_{\mathrm{oi}}=$ the original quantity of the contaminant contained in the glass ( $\mathrm{Ci}$ or $\left.\mathrm{kg}\right)$

$\mathrm{A}=$ the total surface area of the glass waste form $\left(\mathrm{cm}^{2}\right)$

$\mathrm{V}=$ the total initial volume of the glass waste form $\left(\mathrm{cm}^{3}\right)$

$\mathrm{r}=$ the volumetric dissolution rate of glass per area of surface $\left(\mathrm{cm} \mathrm{yr}^{-1}\right)$

In the second configuration, contaminant release from the glass waste form is expressed as a function of a fractional release rate of a contaminant from the waste form. The equation that applies in this case is:

$$
d M / d t=F^{3}(3 / F-t)^{2} M / 9
$$

Kincaid et al. 1998)

where $\quad F=$ the fractional release rate of a specific contaminant from the glass waste form $\left(\mathrm{yr}^{-1}\right)$

$M=$ the initial total activity of the specific contaminant in the source zone (Ci)

The most recent analytical solution for depicting contaminant release rates from glass, uses the STORM model to calculate the normalized flux to the vadose zone by summing the flux at each node across the bottom boundary of the model, and normalizing the total flux according to the amount of each radionuclide in all the waste packages at the start of a simulation (Bacon and McGrail 2001). The analytical solution (i.e., normalized flux, F [ppm/y]) is:

$$
F=\left[\sum f \Delta x \Delta y / I\right]\left(3.1558 \times 10^{7} \mathrm{~s} / \mathrm{y}^{-1}\right)\left(1 \times 10^{6} \mathrm{ppm}\right)
$$


where $\quad f=$ flux across the bottom of an individual grid block $\left(\mu \mathrm{mol} \mathrm{m} \mathrm{m}^{-2} \mathrm{~s}^{-1}\right)$

$\Delta x \Delta y=$ cross-sectional area of an individual grid block $\left(\mathrm{m}^{2}\right)$ and,

$I=$ inventory of the radionuclide in the waste packages $(\mu \mathrm{mol})$, where

$$
I=V_{w p}\left(1-\theta_{T}\right) V_{G} \rho_{G} \gamma
$$

where $\quad V_{w p}=$ volume of the waste packages $\left(\mathrm{m}^{3}\right)$

$\theta_{T}=$ total porosity of the material representing the waste packages (unitless)

$V_{G}=$ fraction of glass in each waste package (unitless)

$\rho_{G}=$ molar density of the specific glass formulation $\left(\mathrm{mols} / \mathrm{m}^{3}\right)$ and,

$\gamma=$ mole fraction of the radionuclide in the specific glass formulation $(\mu \mathrm{mols} / \mathrm{mol})$

Mathematical expressions depicting the third configuration (i.e., the mechanistic approach) can be found in Bacon and McGrail 2001 (Table 4.13).

Sources of data for dissolution (corrosion) and fractional release rates and the mechanistic approach to contaminant release from glass waste forms can be found in Table 4.13.

Table 4.13. Sources of Data for Glass Model

\begin{tabular}{||l|l||}
\hline \multicolumn{1}{|c||}{ Information Source Summary } & \multicolumn{1}{c||}{ Reference } \\
\hline \hline $\begin{array}{l}\text { Glass dissolution and fractional release rates for vitrified waste as } \\
\text { applied to Central Plateau composite analysis }\end{array}$ & Mann et al. 1997 \\
\hline $\begin{array}{l}\text { Fractional release rates for glass waste form in Central Plateau composite } \\
\text { analysis }\end{array}$ & $\begin{array}{l}\text { Kincaid et al. 1998, Appendix D, } \\
\text { p. D.21 and Table D.2 }\end{array}$ \\
\hline Constant corrosion rate for glass waste in support of TWRS EIS & DOE 1996b, pp. F-57-F58 \\
\hline Corrosion rate for ILAW waste package containers & Mann et al. 2000, pp. 51-52 \\
\hline Glass corrosion reaction for ILAW waste & Mann et al. 2000, pp. 42-43 \\
\hline $\begin{array}{l}\text { Dissolution reactions for selected mineral phases associated with ILAW } \\
\text { waste }\end{array}$ & McGrail et al. 1999 \\
\hline Dissolution rates for vitrified waste constituents & Roeck 1993, p. 3-6 \\
\hline Corrosion reactions for ILAW glass & Bacon and McGrail 2001, p. 12 \\
\hline Dissolution equation for ILAW glass & Bacon and McGrail 2001, p. 13 \\
\hline Secondary phase equilibrium constants for ILAW glass & Bacon and McGrail 2001, pp. 14-16 \\
\hline Flux equation for release of ILAW glass constituents to the vadose zone & Bacon and McGrail 2001, pp. 16-17 \\
\hline Kinetic rate parameters for ILAW glass & Bacon and McGrail 2001, p. 14 \\
\hline $\begin{array}{l}\text { ILAW }=\text { Immobilized low-activity waste. } \\
\text { TWRS EIS }=\text { Tank waste remediation system environmental impact statement. }\end{array}$ \\
\hline \hline
\end{tabular}

\subsection{Reactor Compartment Model}

Surplus production reactors contain contamination imbedded in the stainless steel hulls and reactor vessel steels. Sources of contamination also exist within the contained portions of the hulls and reactor vessels. Contaminant release is envisioned as requiring a corrosion model to simulate release of 
contaminants from the reactor compartment steels plus a soil-debris model is to simulate release of contaminants from sources within the reactor compartments.

The contaminant release mechanism for materials and contaminants constituting decommissioned reactor compartment steels is corrosion of the steels. The rate of loss of contaminant for a given contaminant is given by:

$$
D M / d t=-M_{o} F_{r r r} \quad \text { (Developed from information in }
$$

Rhoads et al. 1994, pp. vi and 4.2)

where $\quad \mathrm{M}_{\mathrm{o}}=$ the initial quantity in $\mathrm{Ci}$ or $\mathrm{Kg}$ of contaminant in the steel

$\mathrm{F}_{\mathrm{rrr}}=$ the fractional release rate in $\mathrm{yr}^{-1}$

The fractional release rate is determined by multiplying the corrosion rate of the specific steel $\left(\mathrm{kg} / \mathrm{dm}^{2}\right.$-year) by the total surface area of the steel $\left(\mathrm{dm}^{2}\right)$ and dividing by the total amount of steel containing the contaminant of concern $(\mathrm{kg})$.

Sources of corrosion, solubility, and distribution coefficient data can be found in Tables 4.4 and 4.14. Other data in support of soil-debris model applications to reactor compartment contaminants can be found in Tables 4.4 through 4.8 .

Table 4.14. Sources of Data for Reactor Compartment Model

\begin{tabular}{||l|l||}
\hline \multicolumn{1}{|c|}{ Information Source Summary } & \multicolumn{1}{c||}{ Reference } \\
\hline \hline Corrosion rates of decommissioned nuclear reactor compartment steel & DOE 1996c, pp. 4-12-4-16 \\
\hline Corrosion rates of decommissioned nuclear reactor compartment steel & Rhoads et al. 1994, pp. vi-vii; p. 3.2 \\
\hline $\begin{array}{l}\text { Total PCB solubility for decommissioned nuclear reactor compartment } \\
\text { assessments }\end{array}$ & DOE 1996c, p. 4-32 \\
\hline $\begin{array}{l}\text { Lead solubility for decommissioned nuclear reactor compartment } \\
\text { assessments }\end{array}$ & Rhoads et al. 1992, p. vi, p. 3.10; p. 3.19 \\
\hline Solubility of nickel in Hanford groundwater & Rhoads et al 1994, p. 3.10; pp 3.14-3.16 \\
\hline $\begin{array}{l}\text { Corrosion rates of decommissioned nuclear reactor compartment steels } \\
\text { in Hanford soil }\end{array}$ & NFESC 1993 \\
\hline PCB = Polychlorinated biphenyl. & \\
\hline
\end{tabular}

\subsection{Containment as a Factor Influencing Release of Contaminants from Source Zones}

Containment is a term that recognizes the presence of barriers that contaminants must pass through in order to be free of the engineered system containing the waste. These barriers include waste containment (e.g., steel canisters, drums, reactor compartment hulls, wooden boxes), repository containment (e.g., high-level waste tank structures containing concrete and steel, concrete vaults and high integrity containers, underground steel storage tanks) decommissioned building foundations containing waste, and engineered system bottom liners. Table 4.15 lists sources of data important to the issue of containment. 
Table 4.15. Sources of Data on the Issue of Containment

\begin{tabular}{|c|c|}
\hline Information Source Summary & Reference \\
\hline Corrosion rates of decommissioned nuclear reactor compartment steel & See Table 4.14 \\
\hline $\begin{array}{l}\text { Corrosion rates of decommissioned nuclear reactor compartment steel } \\
\text { in Hanford soil }\end{array}$ & See Table 4.14 \\
\hline Recommended corrosion rates for reactor vessels & See Table 4.14 \\
\hline $\begin{array}{l}\text { Diffusion coefficients for encasement cement concrete and soil fill } \\
\text { materials }\end{array}$ & See Table 4.11 \\
\hline Dissolution rates for fixated wastes (cementitious) & See Table 4.11 \\
\hline Time frame for dissolution of cements & See Table 4.11 \\
\hline Natural analogs of cement and concrete materials & See Table 4.11 \\
\hline Corrosion rates of shielding and metal components of surplus reactors & See Table 4.12 \\
\hline Diffusion of contaminants through engineered system liner & Roeck 1993, p. 2-7 \\
\hline $\begin{array}{l}\text { Modeling assumptions for liner/leachate collection system in ERDF } \\
\text { performance assessment }\end{array}$ & Wood et al. 1995 b, p. 2-21 \\
\hline $\begin{array}{l}\text { Estimated constituent-specific pore diffusivities for silt/bentonite liner } \\
\text { at ERDF }\end{array}$ & Roeck 1993, p. 3-7 \\
\hline Geomembrane liner thicknesses & $\begin{array}{l}\text { Casbon 1995, Tables } 02275-1 \text { and } \\
02275-2 \text {, pp. D-3 and D-4; } \\
40 \text { CFR 258.40, pp. } 149-150\end{array}$ \\
\hline Hydraulic conductivity values for geosynthetic clay liners & EPA 1997, pp. 1-7; 40 CFR 258.40, p.121 \\
\hline Advection in concrete & Kincaid et al. $1995 \mathrm{a}$, p. 3.40 \\
\hline Diffusion through and biodegradation of asphalt barrier & $\begin{array}{l}\text { Kincaid et al. } 1995 \mathrm{a} \text {, pp. 3.49-3.59, } \\
\text { p. } 3.100 \text {, pp. 3.113-3.115 }\end{array}$ \\
\hline Ionic diffusion through asphalt & Kincaid et al. 1995b, Appendix K \\
\hline $\begin{array}{l}\text { Measurement of water vapor diffusion through asphalt diffusion } \\
\text { barrier material }\end{array}$ & Kincaid et al. 1995b, Appendix L \\
\hline $\begin{array}{l}\text { Conceptual model for stability of grout vault ( } 0 \text { to } 100 \text { year period, } \\
100 \text { to } 1,000 \text { year period, } 1,000 \text { to } 10,000 \text { year period, } 10,000 \text { to } \\
100,000 \text { year period) }\end{array}$ & Kincaid et al. 1995b, Appendix O \\
\hline Best estimate crack predictions for the grout vault engineered barriers & Kincaid et al. 1995b, Appendix Q \\
\hline Diffusion through concrete and grout & Kincaid et al. $1995 \mathrm{a}$, p. 3.115 \\
\hline Service life of concrete & Pihlajavaara 1994, pp. 577-586 \\
\hline Corrosion rates of cement waste forms & Criscenti et al. 1996, p. 5.1 \\
\hline $\begin{array}{l}\text { Best estimate diffusion coefficients for constituents migrating through } \\
\text { cement }\end{array}$ & Meyer and Serne 1999, pp. 5.6-5.9 \\
\hline $\begin{array}{l}\text { Best estimate free-water diffusion coefficients and capacity factors for } \\
\text { constituents migrating through cement }\end{array}$ & Meyer and Serne 1999, pp. 5.10-5.11 \\
\hline Corrosion rates of ILAW waste package containers & Mann et al. 2000, pp. 51-52 \\
\hline $\begin{array}{l}\text { Corrosion assessment of storage containers (corrosivity of Hanford } \\
\text { soils) }\end{array}$ & Graves 1994, pp. 7-8 \\
\hline Corrosion assessment of storage containers (container life estimates) & Graves 1994, pp. 9-11 \\
\hline Lifetime of steel barrels in Hanford soil & Criscenti et al. 1996 , p. 2.1 \\
\hline Porewater velocities for cement longevity & Criscenti et al. 1996, p. 2.4 \\
\hline Rate of dissolution of cement contacting migrating soil porewater & Criscenti et al. 1996, p. 5.1 \\
\hline
\end{tabular}


Table 4.15. (contd)

\begin{tabular}{||l|l||}
\hline \multicolumn{1}{|c|}{ Information Source Summary } & \multicolumn{1}{c|}{ Reference } \\
\hline \hline Corrosion of metal drums in Hanford soil & Duncan 1995, pp. 4-8 \\
\hline $\begin{array}{l}\text { Corrosion rates for steel drums in Hanford site solid waste burial } \\
\text { grounds (soil contact and soil shielded storage) }\end{array}$ & $\begin{array}{l}\text { Siciliano 2001, p. 5, p. 28, pp. 33-34, } \\
\text { Figures 3-9, pp. 57-63 }\end{array}$ \\
\hline Steel drum thicknesses & Siciliano 2001, p. 20, pp. 26-27 \\
\hline Corrosion of low-carbon steel drums: 1 year test results & Duncan and Bunnell 1995, pp. 8-16 \\
\hline Corrosion of low-carbon steel drums: 2 year test results & $\begin{array}{l}\text { Anantatmula and Divine 1995, pp. 3-5, } \\
\text { Tables 1 and 2, pp. 6-7 }\end{array}$ \\
\hline Corrosion of 304L stainless steel & Anantatmula and Divine 1995, p. 5 \\
\hline Thicknesses of polyethylene drum liners inside metal drums & Duncan et al. 1995, p. 4 \\
\hline Corrosion rates of carbon steel coupons exposed in tank 241-AN-107 & Anantatmula 2001, Table 1, p. 8 \\
\hline $\begin{array}{l}\text { Estimated remaining service lives for selected Hanford double-shell } \\
\text { tanks }\end{array}$ & Jo et al. 2002, pp. ES-2-ES-3 \\
\hline Discussion of corrosion mechanisms for double-shell tanks & Jo et al. 2002, pp. 3-1-3-7 \\
\hline Discussion of corrosion mechanisms for double-shell tanks & Stewart et al. 2001, pp. 1.16-1.19 \\
\hline $\begin{array}{l}\text { Estimate corrosion rates and double-shell tank service lives following } \\
\text { institution of chemistry control of corrosion }\end{array}$ & Jo et al. 2002, pp 3-7-3-15 \\
\hline Corrosion of carbon steel liners of Hanford high-level waste tanks & $\begin{array}{l}\text { Anantatmula et al. 1994, pp. 2-1, 2-3, and } \\
\text { 2-4. }\end{array}$ \\
\hline $\begin{array}{l}\text { ERDF = Environmental Restoration Disposal Facility. } \\
\text { ILAW = Immobilized low-activity waste. }\end{array}$ & \\
\hline \hline
\end{tabular}

In recent approaches, concrete casks and steel drums were assumed to delay release, however, wooden and cardboard boxes and other types of containment are assumed to offer no barrier to contaminant release (Becker 2002).

\subsubsection{Metal Containment}

For metal containment, process generalized failure competes with process localized failure in determining the timing of release. Generalized failure considers complete degradation of the structure before contaminant is released from the waste. The resulting release is governed by the release mechanism appropriate for the waste type. Generalized failure applies a uniform corrosion rate to the metal container to obtain a value for time to failure. Uncertainty in the value of time of failure can be addressed by what is known about the uncertainty in the uniform corrosion rate and wall thickness for specific types of metal containers. Uncertainty is also introduced based on the way the drums are buried in the waste site. Stacked drums fail at a slower rate compared to drums that are dumped into pits without attempting to maintain their integrity. Localized failure is assumed to occur by way of pitting corrosion which permits water to access the waste in ever increasing amounts as the container degrades to complete failure. Localized failure rates can be used to vary the infiltration rate input to the soil-debris model and the amount of inventory made available for release by way of the diffusion mechanism. Localized failure has been modeled for carbon steel drums (Sullivan and Suen 1989). 
For stacked drums, a normal distribution for failure time (22.6 \pm 9.9 years) has been applied to stacked drums at the Idaho National Engineering and Environmental Laboratory Subsurface Disposal Area (Becker 1997). For dumped drums, a certain percentage of the drums were assumed to fail at the time of disposal $(28.5 \%)$ with the remainder failing based on a normal distribution for failure time $(11.7 \pm 5$ years). The effects of disposal practices can be considered for either generalized or localized failure.

\subsubsection{Concrete Containment}

Because the history of modern concrete is short ( $\sim 100$ years) relative to the required prediction of service life (time to concrete failure), the task is difficult. This is because concrete degradation is governed by a number of competing processes. Key processes discussed in the assessments included sulfate attack, corrosion of reinforcing steel, alkali-aggregate reactions and water leaching. Modeling of each of these processes on predicting concrete service life has been performed, however, a model that predicts concrete service life based on the collective effects of these processes remains elusive (Clifton and Knab 1989; Walton, Plansky and Smith 1990). Blind extrapolation of empirical data is difficult to defend technically, but is frequently the only option to no prediction at all. As a result, it has been concluded that the classical conservative analysis mode of calculations or the use of an estimated design lifetime may be the most appropriate for determining concrete service life. A design lifetime goal of 300 years has been assigned to high integrity containers (NRC 1991). Correlations have been developed between service life of concrete and concrete compressive strength for four types of environments (i.e., strain classes) (Pihlajavaara 1994). 


\subsection{References}

Anantatmula, R.P. 2001. Characterization of Corrosion Probe Coupons Exposed in Tank 241-AN-107. RPP-9504, CH2M HILL Hanford Group, Inc., Richland, Washington.

Anantatmula, R.P. and J.R. Divine. 1995. Corrosion of Low-Carbon Steel Under Environmental Conditions at Hanford: Two-Year Soil-Corrosion Test Results. WHC-EP-0891, Westinghouse Hanford Company, Richland, Washington.

Anatatatmula, R.P., E.B. Schwenk, and M.J. Danielson. 1994. Characterization of the Corrosion Behavior of the Carbon Steel Liner in Hanford Site Single-Shell Tanks. WHC-EP-0772, Rev. 0, Westinghouse Hanford Company, Richland, Washington.

Bacon, D.H. and B.P. McGrail. 2001. Waste Form Release Calculations for the 2001 Immobilized LowActivity Waste Performance Assessment. PNNL-13369, Pacific Northwest National Laboratory, Richland, Washington.

Becker, B.H. 1997. Selection and Development of Models Used in the Waste Area Group 7 Baseline Risk Assessment. INEL-EXT-97-00391, Idaho National Engineering and Environmental Laboratory, Lockheed Martin Idaho Technologies Company, Idaho Falls, Idaho.

Becker, B. 2002. Source Release Modeling for the Idaho National Engineering and Environmental Laboratory's Subsurface Disposal Area. INEEL/CON-02-00159, Idaho National Engineering and Environmental Laboratory, Idaho Falls, Idaho.

BHI. 1999. Cleanup Verification Package for the 116-C-1 Process Effluent Trench. CVP-98 00006, Rev. 0, Bechtel Hanford, Inc., Richland, Washington.

Bryce, R.W., C.T. Kincaid, P.W. Eslinger, and L.F. Morasch. 2002. An Initial Assessment of Hanford Impact Performed with the System Assessment Capability. PNNL-14027, Pacific Northwest National Laboratory, Richland, Washington.

Buck, J.W., L.M. Bagaasen, M.P. Bergeron, G.P. Streile, L.H. Staven, K.J. Castleton, G.M. Gelston, D.L. Strenge, K.M. Krupka, and R.J. Serne. 1996. Long-Term-Consequence Analysis of No Action Alternative 2. Support Information for the Waste Isolation Pilot Plant Disposal-Phase Supplemental Environmental Impact Statement. PNNL-11251, Pacific Northwest National Laboratory, Richland, Washington.

Burbank, D.A. 2001. Conceptual Design Report for Immobilized Low-Activity Waste Disposal Facility, Project $W-520$. RPP-7908 Rev. 0, CH2M HILL Hanford Group, Inc.

Cantrell, K.J., R.J. Serne, and G.V. Last. 2002. Hanford Contaminant Distribution Coefficient Database and Users Guide. PNNL-13895, Pacific Northwest National Laboratory, Richland, Washington. 
Casbon, M.A. 1995. Evaluation of Liner/Leachate Chemical Compatibility for the Environmental Restoration Disposal Facility. BHI-00359, Rev. 00, Bechtel Hanford, Inc., Richland, Washington.

Chen, G., T.A. Ferryman, K.M. Remund, S.A. Hartley, F. Gao, C.A. Lo Presti, T.J. DeForest, J.G. Hill, C.A. Weier, B.G. Amidan, and D.K. Gemeinhart. 1998. Methodology for Uncertainty Estimation of Hanford Tank Chemical and Radionuclide Inventories and Concentrations. PNNL-11842, Pacific Northwest National Laboratory, Richland, Washington.

Clifton, J.R. and L.I. Knab. 1989. Service Life of Concrete. NUREG/CR-5546, U.S. Nuclear Regulatory Commission, Washington, D.C.

Colton, N.G. 1995. Sludge Pretreatment Chemistry Evaluation: Enhanced Sludge Washing Separation Factors. PNL-10512, Pacific Northwest Laboratory, Richland, Washington.

Colton, N.G. 1996. Status Report: Pretreatment Chemistry Evaluation-Wash and Leach Factors for the Single Shell Tank Waste Inventory. PNNL-11290, Pacific Northwest National Laboratory, Richland, Washington.

Criscenti, L.J., R.J. Serne, K.M. Krupka, and M.I. Wood. 1996. Predictive Calculations to Assess the Long-Term Effect of Cementitious Materials on the pH and Solubility of Uranium (VI) in a Shallow and Disposal Environment. PNNL-11182, Pacific Northwest National Laboratory, Richland, Washington.

DOE. 1987. Final Environmental Impact Statement, Disposal of Hanford Defense High-Level, Transuranic and Tank Wastes, Hanford Site, Richland, Washington. DOE/EIS-0113, Vol. 1, U.S. Department of Energy, Washington, D.C.

DOE. 1989. Decommissioning of Eight Surplus Production Reactors at the Hanford Site, Richland, Washington. DOE/EIS-0119D, U.S. Department of Energy, Washington, D.C.

DOE. 1994. Remedial Investigation and Feasibility Study Report for the Environmental Restoration Disposal Facility. DOE/RL-93-99, Rev. 1, U.S. Department of Energy, Richland, Washington.

DOE. 1996a. Tank Waste Remediation System, Hanford Site, Richland, Washington, Final Environmental Impact Statement. DOE/EIS-0189, Volume 5, U.S. Department of Energy, Richland, Washington.

DOE. 1996b. Tank Waste Remediation System, Hanford Site, Richland, Washington, Final Environmental Impact Statement. DOE/EIS-0189, Volume 4, U.S. Department of Energy, Richland, Washington.

DOE. 1996c. Final Environmental Impact Statement on the Disposal of Decommissioned, Defueled Cruiser, Ohio Class, and Los Angeles Class Naval Reactor Plants. DOE/EIS-0259, U.S. Department of the Navy, Washington, D.C.

DOE. 1997. Waste Site Grouping for 200 Areas Soil Investigations. DOE/RL-96-81, Rev. 0, U.S. Department of Energy, Richland Operations Office, Richland, Washington. 
DOE. 1998. Phase I Feasibility Study for the Canyon Disposition Initiative. DOE/RL-97-11, Rev. 1, U.S. Department of Energy, Richland, Washington.

DOE. 1999. Retrieval Performance Evaluation Methodology for the AX Tank Farm. DOE/RL-98-72, U.S. Department of Energy, Richland, Washington.

DOE. 2002. Draft Hanford Site Solid (Radioactive and Hazardous) Waste Program Environmental Impact Statement, Richland, Washington: Volume II-Appendixes A through L. DOE/EIS-0286D, U.S. Department of Energy, Richland, Washington.

DOHEW. 1970. Radiological Training Handbook. U.S. Department of Health, Education, and Welfare, Public Health Service, Rockville, Maryland.

Duncan, D.R. 1995. Description of the Solid Waste Container Corrosion Program at the Hanford Site. WHC-SA-2707-FP, Westinghouse Hanford Company, Richland, Washington.

Duncan, D.R. and L.R. Bunnell. 1995. Measurements of the Corrosion of Low-Carbon Steel Drums Under Environmental Conditions at Hanford: One-Year Test Results. WHC-EP-0859, Westinghouse Hanford Company, Richland, Washington.

Duncan, D.R., D.I. Weyns-Rollosson, J.A. Pottmeyer, and T.J. Stratton. 1995. A History of Waste Packaging at the Hanford Site. WHC-SA-2772-FP, Westinghouse Hanford Company, Richland, Washington.

Dunkelman, M. 2000. Groundwater Pathway Analysis for the Commercial Low-level Radioactive Waste Disposal Site, Richland, Washington. Washington State Department of Health, Division of Radiation Protection, Olympia, Washington.

Engleman, R.E., R E. Lewis, D.C. Stromswold, and J.R. Hearst. 1995. Calibration Models for Measuring Moisture in Unsaturated Formations by Neutron Logging. PNL-10801, Pacific Northwest Laboratory, Richland, Washington.

EPA. 1997. Geosynthetic Clay Liners Used in Municipal Solid Waste Landfills. EPA 530-F-97-002. U.S. Environmental Protection Agency, Washington, D.C.

Eslinger, P.W., D. Engel, L. Gerhardstein, C. Lo Presti, W. Nichols, and D. Strenge. 2002. User Instructions for the Systems Assessment Capability, Rev. 0, Computer Codes. Volume 1: Inventory, Release, and Transport Modules. PNNL-13932, Volume 1, Pacific Northwest National Laboratory, Richland, Washington.

Fayer, M.J., E.M. Murphy, J.L. Downs, F.O. Kahn, C.W. Lindenmeier, and B.N. Bjornstad. 1999. Recharge Data Package for the Immobilized Low-Activity Waste 2001 Performance Assessment. PNNL-13033, Pacific Northwest National Laboratory, Richland, Washington.

Gee, G. W., M. J. Fayer, M. L. Rockhold, and M. D. Campbell. 1992. "Variations in Recharge at the Hanford Site." Northwest Science 66:237-250. 
Gilbert, T.L., C. Yun, Y.C. Yuan, A.J. Zielen, M.J. Jusko, and A. Wallo, III. 1989. A Manual for Implementing Residual Radioactive Material Guidelines. DOE/CH/8901, U.S. Department of Energy, Washington, D.C.

Graves, C.E. 1994. Corrosion Assessment of Dry Fuel Storage Containers. WHC-EP-0804, Westinghouse Hanford Company, Richland, Washington.

Gray, W.J. 1982. "A Study of the Oxidation of Graphite in Liquid Water for Radioactive Waste Storage Applications.” Rad. Waste Mgmt. 3:137-149.

Greenhalgh, W.O. 1995. Pre-1970 Transuranic Waste at the Hanford Site. WHC-SD-WM-ES-325, Rev. 0, Westinghouse Hanford Company, Richland, Washington.

Jo, J., R.P. Anantatmula, C.P. Shaw, H. Berman, D.M. Ogden, and M.J. Thurgood. 2002. Technical Basis for Caustic Additions to Tanks 241-AY-101, 241-AY-102, 241-AN-102, and 241-AN-107.

RPP-8173, Rev. 1, CH2M HILL Hanford Group, Inc., Richland, Washington.

Josephson, W.S. 1996. High Integrity Container Evaluation for Solid Waste Disposal Burial Containers. WHC-SD-WM-TI-761, Rev. 0, Westinghouse Hanford Company, Richland, Washington.

Khaleel, R., T.E. Jones, A.J. Kneep, F.M. Mann, D.A. Meyers, P.M. Rogers, R.J. Serne, and M.I. Wood. 2000. Modeling Data Package for S-SX Field Investigation Report. RPP-6296, Rev. 0, CH2M HILL Hanford Group, Inc., Richland, Washington.

Khaleel, R., M.P. Connelly, D. Crumpler, T.E. Jones, A.J. Knepp, F.M. Mann, B. McMahon, C.W. Miller, and M.I. Wood. 2002. Modeling Data Package for an Initial Assessment of Closure for C Tank Farm. RPP-13310, Rev. 0, CH2M HILL Hanford Group, Inc., Richland, Washington.

Kincaid, C.T., J.W. Shade, G.A. Whyatt, M.G. Piepho, K. Rhoads, J.A. Voogd, J.H. Westsik, Jr., M.D. Freshley, K.A. Blanchard, and B.G. Lauzon. 1995a. Performance Assessment of Grouted Double-Shell Tank Waste Disposal at Hanford, Volume 1. WHC-SD-WMEE-004, Rev. 1, Westinghouse Hanford Company, Richland, Washington.

Kincaid, C.T., J.W. Shade, G.A. Whyatt, M.G. Piepho, K. Rhoads, J.A. Voogd, J.H. Westsik, Jr., M.D. Freshley, K.A. Blanchard, and B.G. Lauzon. 1995b. Performance Assessment of Grouted Double-Shell Tank Waste Disposal at Hanford, Volume 2. WHC-SD-WMEE-004, Rev. 1, Westinghouse Hanford Company, Richland, Washington.

Kincaid, C.T., M.P. Bergeron, C.R. Cole, M.D. Freshley, N.L. Hassig, V.G. Johnson, D.I. Kaplan, R.J. Serne, G.P. Streile, D.L. Strenge, P.D. Thorne, L.W. Vail, G.A. Whyatt, and S.K. Wurstner. 1998. Composite Analysis for Low-Level Waste Disposal in the 200 Area Plateau of the Hanford Site. PNNL-11800, Pacific Northwest National Laboratory, Richland, Washington.

Kline, N.W. 1995. Development of a Unit Cell Model for Interim Performance Assessment of Vitrified Low-Level Waste Disposal. WHC-SD-WM-RPT-189, Rev. 0, Westinghouse Hanford Company, Richland, Washington. 
Kline, N.W. 1996. Unit Cell Modeling in Support of Interim Performance Assessment of Low-Level Tank Waste Disposal. WHC-SD-WM-RPT-225, Westinghouse Hanford Company, Richland, Washington.

Kovak, M.W., M.S. Chu, T.A. Mattingly, J.D. Johnson, and J.T. McCord. 1990. Background Information for the Development of a Low-Level Waste Performance Assessment Methodology. SAND 90-0375, Vol. 5. Sandia National Laboratory, Albuquerque, New Mexico.

Krupka, K.M. and R.J. Serne. 1998. Effects on Radionuclide Concentrations by Cement/Ground-Water Interactions in Support of Performance Assessment of Low-Level Radioactive Waste Disposal Facilities. PNNL-11408, Pacific Northwest National Laboratory, Richland, Washington.

Last, G.V., D.G. Horton, W.E. Nichols, M.J. Fayer, B.N. Bjornstad, T.J. Gilmore, K.J. Cantrell, K.M. Krupka, and R. Khaleel. 2001. Vadose Zone Data for Initial Assessment Performed with the System Assessment Capability (Revision 0). Available at http://www.hanford.gov/cp/gpp/modeling/sacarchive.cfm

Lokken, R.O. 1992. Formulation Verification Study Results for Tank 106-AN Waste. PNL-7966, Pacific Northwest Laboratory, Richland, Washington.

Lokken, R.O., P.F.C. Martin, and J.W. Shade. 1992. Durability of Double-Shell Tank Waste Grouts. PNL-7835, Pacific Northwest Laboratory, Richland, Washington.

Mann, F.M., C.R. Eiholzer, Y. Chen, N.W. Kline, A.H. Lu, B.P. McGrail, P.D. Rittman, G.F. Williamson, J.A. Voogd, N.R. Brown, and P.E. LaMont. 1997. Hanford Low-Level Tank Waste Interim Performance Assessment. HNF-EP-0884, Rev. 1, Lockheed Martin Hanford Corporation, Richland, Washington.

Mann, F.M., R.J. Puigh, II, P.D. Rittmann, N.W. Kline, J.A. Voogd, Y. Chen, C.R. Eiholzer, C.T. Kincaid, B.P. McGrail, A.H. Lu, G.F. Williamson, N.R. Brown, and P.E. Lamont. 1998. Hanford Immobilized Low-Activity Tank Waste Performance Assessment. DOE/RL-97-69, U.S. Department of Energy, Richland Operations Office, Richland, Washington.

Mann, F.M., S.H. Finfrock, E.J. Freeman, R.J. Puigh, II, D.H. Bacon, M.P. Bergeron, B.P. McGrail, and S.K. Wurstner. 2000. White Paper. Updating Conclusions of the 1998 ILAW Performance Assessment. DOE/ORP-2000-07, Revision 0, U.S. Department of Energy, Office of River Protection, Richland, Washington.

Martin, P.F.C. and R.O. Lokken. 1992. Characterization of a Low-Level Radioactive Waste Grout: Sampling and Test Results. PNL-8067, Pacific Northwest Laboratory, Richland, Washington.

Mattigod, S.V., G.A. Whyatt, R.J. Serne, P.F. Martin, K.E. Schwab, and M.I. Wood. 2001. Diffusion and Leaching of Selected Radionuclides (I-129, Tc-99, and U) through Category 3 Waste Encasement Cement Concrete and Soil Fill Material: Progress Report for 2001. PNNL-13639, Pacific Northwest National Laboratory, Richland, Washington. 
McGrail, B.P., D.H. Bacon, J.P. Icenhower, W.L. Ebert, P.F. Martin, H.T. Schaef, and E.A. Rodriquez. 1999. Waste Form Release Data Package for the 2001 Immobilized Low-Activity Waste Performance Assessment. PNNL-13043, Pacific Northwest National Laboratory, Richland, Washington.

Meyer, P.D. and R.J. Serne. 1999. Near-Field Hydrology Data Package for the Immobilized LowActivity Waste 2001 Performance Assessment. PNNL-13035, Pacific Northwest National Laboratory, Richland, Washington.

Miller, R.L. and J.M. Steffes. 1987. Radionuclide Inventory and Source Terms for the Surplus Production Reactors at Hanford. UNI-3714, Rev. 1, UNC Nuclear Industries, Richland, Washington.

NFESC. 1993. Corrosion Behavior of HY-80 Steel, Type 304 Stainless Steel, and Inconel Alloy 600 at 218-E-12B Burial Ground, Hanford, WA. TR-2001-SHR, Naval Facilities Engineering Service Center, Point Hueneme, California.

NRC. 1991. Technical Position on Waste Form Revision 1, U.S. Nuclear Regulatory Commission, Office of Nuclear Material Safety Safeguards, Washington, D.C.

Peterson, R.E., R.F. Raidl, and C.W. Denslow. 1996. Conceptual Site Model for Groundwater Contamination at 100 BC-5, 100 KR-4, 100 HR-3, and 100 FR-3 Operable Units. BHI-00917, Rev. 0, Bechtel Hanford, Inc., Richland, Washington.

Pihlajavaara, P. 1994. Estimation of Service Life of Concrete under Different Environments, Volume 1. R.N. Parkins (ed.), NACE International, Houston, Texas.

Resource Conservation and Recovery Act (RCRA). 1976. Public Law 94-580, as amended, 90 Stat. 2795, 42 USC 6901 et seq.

Rhoads, K., B.N. Bjornstad, R.E. Lewis, S.S. Teal, K.J. Cantrell, R.J. Serne, J.L. Smoot, C.T. Kincaid, and S.K. Wurstner. 1992. Estimation of the Release and Migration of Lead through the Soils and Groundwater at the Hanford Site 218-E-12B Burial Ground. PNL-8356, Vol. 1, Pacific Northwest Laboratory, Richland, Washington.

Rhoads, K., B.N. Bjornstad, R.E. Lewis, S.S. Teel, K.J. Cantrell, R.J. Serne, L.H. Sayer, J.L. Smoot, J.E. Szecsody, M.S. Wigmosta, and S.K. Wurstner. 1994. Estimation of the Release and Migration of Nickel Through Soil and Groundwater at the Hanford Site 218-E-218 Burial Ground. PNL-9791, Pacific Northwest Laboratory, Richland, Washington.

Riley, R.G. and C.A. Lo Presti. 2001a. Data Catalog for Models Simulating Release of Contaminants from Hanford Site Waste Sources. PNNL-13666, Pacific Northwest National Laboratory, Richland, Washington.

Riley, R. G. and C. A. Lo Presti. 2001b. Release Data for Initial Assessment Performed with the System Assessment Capability (Revision 0). 
Rockhold, M.L., M.J. Fayer, G.W. Gee, and C.T. Kincaid. 1995. Estimation of Natural Groundwater Recharge for the Performance Assessment of a Low-Level Waste Disposal Facility at the Hanford Site. PNL-10508, Pacific Northwest Laboratory, Richland, Washington.

Roeck, F.V. 1993. Screening Performance Assessment/Risk Assessment for the Proposed Environmental Restoration Disposal Facility (ERDF). WHC-SD-EN-TI-201, Westinghouse Hanford Company, Richland, Washington.

Romano, T. and R.L. Miller. 1995. Production Reactor Disposal on the Hanford Site. WHC-SA-2786-FP, Westinghouse Hanford Company, Richland, Washington.

Rood, A.S. 2000. Further Evaluation of Groundwater Concentrations for Different Covers at the U.S. Ecology Low-level Waste Disposal Site, Hanford, Washington, Using GWSCREEN 2.5 and Minimizing the Cover's Effect at Depth. K-Spar Inc. Scientific Consulting, Rigby, Idaho.

Schalla, R., R.W. Wallace, R.L. Aaberg, S.P. Airhart, D.J. Bayes, J.V.M. Carlile, C.S. Cline, D.I. Dennison, M.D. Freshley, P.R. Heller, E.J. Jensen, K.B. Olsen, R.R. Parkhurst, J.T. Rieger, and E.J. Westergard. 1988. Interim Characterization Report for the 300 Area Process Trenches. PNL-6716, Pacific Northwest Laboratory, Richland, Washington.

Serne, R.J. and M.I. Wood. 1990. Hanford Waste-Form Release and Sediment Interaction. PNL-7297, Pacific Northwest Laboratory, Richland, Washington.

Serne, R.J., R.O. Lokken, and L.J. Criscenti. 1992. "Characterization of Grouted Low-Level Waste to Support Performance Assessment.” Waste Management 12:271-287.

Siciliano, E.R. 2001. Corrosion Rates and Inspection Frequencies for Steel Drums in the Hanford Site Solid Waste Burial Grounds. HNF-7165, Rev. 0, Fluor Hanford, Richland, Washington.

Stenner, R.D., K.H. Cramer, K.A. Higley, S.J. Jette, D.A. Lamar, T.J. McLaughlin, D.R. Sherwood, and N.C. Van Houten. 1988. Hazard Ranking System Evaluation of CERCLA Inactive Waste Sites at Hanford - Engineered Facility Sites (HISS Data Base). PNL-6456, Volumes 2 and 3, Pacific Northwest Laboratory, Richland, Washington.

Stewart, C.W., S.H. Bush, H.S. Berman, C.J. Czajkowski, J.R. Divine, G.J. Posakony, A.B. Johnson, M.R. Elmore, D.A. Reynolds, R.P. Anantatmula, R.L. Sindelar, and P.E. Zapp. 2001. Expert Panel Recommendations for Hanford Double-Shell Tank Life Extensions. PNNL-13571, Pacific Northwest National Laboratory, Richland, Washington.

Streile, G.P., K.D. Shields, J.L. Stroh, L.M. Bagaasen, G. Whelan, J.P. McDonald, J.G. Droppo, and J.W. Buck. 1996. The Multimedia Environmental Pollutant Assessment System (MEPAS): Source-Term Release Formulations. PNNL-11248, Pacific Northwest National Laboratory, Richland, Washington.

Sullivan, T.M. and C.J. Suen. 1989. Low-Level Waste Shallow Land Disposal Source Term Model: Data Input Guides. BNL-NUREG-55206, Brookhaven National Laboratory, Upton, New York. 
Taylor, W.J. 1999. Contract No. DE-AC-06-99RL14047-Decision to Change the Immobilized LowActivity Waste (ILAW) Disposal Baseline to Proceed with the Remote-Handled Trench Alternative, Letter 99-DPD-066 (correspondence control number 9958849), Department of Energy, Richland, Washington, December 1, 1999.

Walton, J.C., L.E. Plansky, and R.W. Smith. 1990. Models for Estimation of Service Life of Concrete Barriers in Low-Level Radioactive Waste Disposal. NUREG/CR-5542, U.S. Nuclear Regulatory Commission, Washington, D.C.

WDOE. 2000. Commercial Low-level Radioactive Waste Disposal Site, Richland, Washington. Draft Environmental Impact Statement. Washington State Department of Ecology and Washington State Department of Health, Olympia, Washington.

WHC. 1994a. Tank Farm Surveillance and Waste Status Summary Report for March 1994. WHC-EP-0182-72, Westinghouse Hanford Company, Richland, Washington.

WHC. 1994b. Characterization of the Corrosion Behavior of the Carbon Steel Liner in Hanford SingleShell Tanks. WHC-EP-0772, Rev. 0, Westinghouse Hanford Company, Richland, Washington.

White, I.F., G.M. Smith, L.J. Saunders, C.J. Kaye, T.J. Martin, G.H. Clarke, and M.W. Wakerley. 1984. Assessment of Management Modes for Graphite from Reactor Decommissioning. EUR-9232, Commission of the European Communities, Luxembourg.

Wood, M.I., R. Khaleel, P.D. Rittmann, A.H. Lu, S.H. Finfrock, R.J. Serne, K.J. Cantrell, and T.H. DeLorenzo. 1995a. Performance Assessment for the Disposal of Low Level Waste in the 200 West Area Burial Grounds. WHC-EP-0645, Westinghouse Hanford Company, Richland, Washington.

Wood, M.I., R. Khaleel, P.D. Rittmann, A.H. Lu, S.H. Finfrock, and T.H. DeLorenzo. 1995 b. Environmental Restoration Disposal Facility Performance Assessment. BHI-00169, Rev. 00, Bechtel Hanford, Inc., Richland, Washington.

Wood, M.I., R. Khaleel, P.D. Rittmann, S.H. Finfrock, T.H. DeLorenzo, and D.Y. Garbrick. 1996. Performance Assessment for the Disposal of Low-Level Waste in the 200 East Burial Grounds. WHC-SD-WM-TI-730, Rev. 0, Westinghouse Hanford Company, Richland, Washington.

Yu, C., A.J. Zielen, J.J. Cheng, Y.C. Yuan, L.G. Jones, D.J. LePoire, Y.Y. Wang, C.O. Loureiro, E. Gnanapragasam, E. Faillace, A. Wallo, III, W.A. Williams, and H. Peterson. 1993. Manual for Implementing Residual Radioactive Material Guidelines Using RESRAD. Version 5.0, ANL/EAD/LD-2, Argonne National Laboratory, Argonne, Illinois. 


\section{Distribution}

No. of

Copies

ONSITE

DOE Office of River Protection

R. M. Yasek

7 DOE Richland Operations Office

B. L. Foley

J. P. Hanson

R. D. Hildebrand

J. G. Morse

K. M. Thompson

Public Reading Room (2)

2 Bechtel Hanford Inc.

K. R. Fecht

A. M. Nazarali

3 C2M HILL Hanford, Inc.

L. C. Swanson

C. W. Miller

M. P. Connelly

5 CH2M HILL Hanford Group, Inc.

S. W. Clark

F. M. Mann

D. A. Myers

A. J. Knepp

F. J. Anderson

Fluor Federal Services, Inc.

R. Khaleel
H9-01

P7-62

K8-50

A5-13

A5-13

A5-13

H2-53

H0-02

H9-02

H9-02

H9-03

E6-35

H0-22

H0-22

H0-22

E6-35

B4-43
No. of

Copies

5 Fluor Hanford, Inc.

B. H. Ford

E6-35

M. I. Wood

H8-44

T. N. Fogwell

E6-35

M. E. Todd

H6-35

V. J. Rohay

H0-19

\section{Pacific Northwest National Laboratory}

B. N. Bjornstad K6-81

R. W. Bryce K6-75

A. L. Bunn K6-85

J. G. Bush K6-96

K. J. Cantrell K6-81

W. J. Deutsch K6-81

J. L. Devary K6-96

R. L. Dirkes K6-75

M. J. Fayer K9-33

E. J. Freeman K9-36

M. D. Freshley H0-21

G. W. Gee K9-33

D. G. Horton K6-81

C. T. Kincaid K9-33

G. V. Last K6-81

C. A. LoPresti K5-12

W. J. Martin K6-81

B. P. McGrail K6-81

W. E. Nichols K9-33

T. L. Page K9-02

R. G. Riley (10) K6-96

R. J. Serne K6-81

P. D. Thorne K9-33

S. B. Yabusaki K9-36

J. M. Zachara K8-96

Hanford Technical Library (2) P8-55 